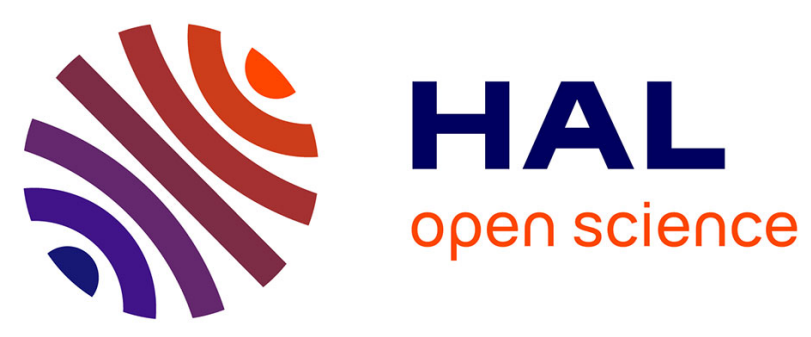

\title{
Synthesis and Catalytic Use of Polar Phosphinoferrocene Amidosulfonates Bearing Bulky Substituents at the Ferrocene Backbone
}

Petr Vosáhlo, Léa Radal, Marine Labonde, Ivana Císařová, Julien Roger, Nadine Pirio, Jean- Cyrille Hierso, Petr Štěpnička

\section{To cite this version:}

Petr Vosáhlo, Léa Radal, Marine Labonde, Ivana Císařová, Julien Roger, et al.. Synthesis and Catalytic Use of Polar Phosphinoferrocene Amidosulfonates Bearing Bulky Substituents at the Ferrocene Backbone. Organometallics, 2021, 40 (12), pp.1934-1944. 10.1021/acs.organomet.1c00244 . hal03467878

\section{HAL Id: hal-03467878 https://hal.science/hal-03467878}

Submitted on 6 Dec 2021

HAL is a multi-disciplinary open access archive for the deposit and dissemination of scientific research documents, whether they are published or not. The documents may come from teaching and research institutions in France or abroad, or from public or private research centers.
L'archive ouverte pluridisciplinaire HAL, est destinée au dépôt et à la diffusion de documents scientifiques de niveau recherche, publiés ou non, émanant des établissements d'enseignement et de recherche français ou étrangers, des laboratoires publics ou privés. 


\title{
Synthesis and Catalytic Use of Polar Phosphinoferrocene Amidosulfonates Bearing Bulky Substituents at the Ferrocene Backbone
}

\author{
Petr Vosáhlo, ${ }^{\mathrm{a}}$ Léa Radal, ${ }^{\mathrm{b}}$ Marine Labonde, ${ }^{\mathrm{b}}$ Ivana Císařová, ${ }^{\mathrm{a}}$ Julien Roger, ${ }^{\mathrm{b}}$ Nadine Pirio, ${ }^{\mathrm{b}}$ Jean- \\ Cyrille Hierso, ${ }^{\text {** }}$ and Petr Štěpnička ${ }^{\mathrm{a} *}$
}

${ }^{a}$ Department of Inorganic Chemistry, Faculty of Science, Charles University, Hlavova 2030, 128 40 Prague, Czech Republic; ${ }^{\mathrm{b}}$ Institut de Chimie Moléculaire de l'Université de Bourgogne (ICMUB) UMR CNRS 6302, Université Bourgogne Franche-Comté (UBFC), 9 avenue Alain Savary, 21078 Dijon, France

\begin{abstract}
Anionic phosphinoferrocene amidosulfonates bearing sterically demanding $t$-butyl substituents in positions 3 and $3^{\prime}$ of the ferrocene scaffold, viz. rac- $\left(\mathrm{Et}_{3} \mathrm{NH}\right)\left[\mathrm{Fe}\left(\eta^{5}-t \mathrm{BuC}_{5} \mathrm{H}_{3} \mathrm{PR}_{2}\right)\left(\eta^{5}-t \mathrm{BuC}_{5} \mathrm{H}_{3} \mathrm{C}(\mathrm{O}) \mathrm{NHCH}_{2} \mathrm{SO}_{3}\right)\right](\mathrm{R}=\mathrm{phenyl}$ and cyclohexyl) were synthesized by amidation of the corresponding phosphinocarboxylic acids, $\left[\mathrm{Fe}\left(\eta^{5}-t \mathrm{BuC} \mathrm{C}_{5} \mathrm{H}_{3} \mathrm{PR}\right)\left(\eta^{5}-\right.\right.$ $\left.\left.t \mathrm{BuC}_{5} \mathrm{H}_{3} \mathrm{CO}_{2} \mathrm{H}\right)\right]$. These ditopic polar phosphinoferrocenes and their non-t-butylated analogues have been used as ligands to prepare zwitterionic ( $\eta^{3}$-allyl)palladium(II) complexes $\left[\mathrm{Pd}\left(\eta^{3}-\mathrm{C}_{3} \mathrm{H}_{5}\right)\left\{\mathrm{Fe}\left(\eta^{5}-\mathrm{R}^{\prime} \mathrm{C}_{5} \mathrm{H}_{3} \mathrm{PR}_{2}\right)\left(\eta^{5}-\mathrm{R}^{\prime} \mathrm{C}_{5} \mathrm{H}_{3} \mathrm{C}(\mathrm{O}) \mathrm{NHCH}_{2} \mathrm{SO} \mathrm{O}_{3}\right)\right\}\right]\left(\mathrm{R}^{\prime}=\right.$ $\mathrm{H}, t \mathrm{Bu}, \mathrm{R}=\mathrm{Ph}, \mathrm{Cy})$. Depending on the isolation procedure and crystallization conditions, some complexes were isolated in two isomeric forms which differed by the coordination of the amidosulfonate pendant group, where either amide or sulfonated oxygen ligated the $\mathrm{Pd}(\mathrm{II})$ centre. The preference for coordination of the amide or sulfonate oxygen atoms has been explained by interplay of electrostatic and solvation effects and further supported by DFT calculations. The ( $\eta^{3}$ allyl)Pd(II) complexes have been applied as defined pre-catalysts for Pd-catalysed $\mathrm{C}-\mathrm{H}$ arylation of unprotected indole with aryl iodides in polar solvents. Under the optimized reaction conditions at $100^{\circ} \mathrm{C}$ in water, $\mathrm{C} 2$-arylation proceeded selectively with various aryl iodides to produce the respective 2-arylindoles in acceptable yields at low catalyst loading (1 mol.\% Pd) and in the absence of any phase transfer agent. The catalyst possessing $t$-butyl groups at the ferrocene core and an electron-rich dicyclohexylphosphino group exhibited the best catalytic performance.
\end{abstract}

\section{INTRODUCTION}

Homogeneous catalysis by transition metal complexes relies on the development of suitable supporting ligands. ${ }^{1}$ Phosphines are particularly attractive due to their tuneable steric and electronic properties that can be used to control the course of catalytic processes ${ }^{2}$ by means of substituent modification and by incorporation of additional functional groups. ${ }^{3}$ The introduction of polar hydrophilic substituents into the ligands is of particular practical importance, as it allows for the transfer of catalytic reactions from purely organic solvents to more innocuous aqueous media. ${ }^{4}$ Although numerous polar groups have been used as solubilizing moieties for phosphine ligands (e.g., charged ammonium, guanidium and carboxylate fragments), sulfonated phosphines remain the most successful ligands for aqueous catalysis. However, their practical success is partially compromised by challenging synthesis, as synthetic methods for introducing phosphine and sulfonate moieties are often incompatible due to the sensitivity of the phosphine groups towards oxidation. ${ }^{4}$
To alleviate these problems, we have recently devised an alternative approach based on amide coupling reactions ${ }^{5}$ between phosphinocarboxylic acids and aminosulfonic acids, producing functional amidophosphine ligands $\mathbf{1}^{\mathbf{R}}$ (Scheme 1, left; $\mathrm{R}=\mathrm{Ph}, \mathrm{Cy}$ ). ${ }^{6,7}$ These coupling reactions proceed with good to excellent yields, employ stable, safe, and readily accessible starting materials, and typically produce pure crystalline products. ${ }^{8}$ Utilizing this approach, we synthesized several phosphinoferrocene amidosulfonates, which proved to be useful ligands for catalytic reactions in aqueous systems. ${ }^{9}$ Notably, even a single amidosulfonate tag was sufficient to overcome the hydrophobicity of phosphinoferrocene ligands, which limits their applications in aqueous catalysis. ${ }^{10}$

Scheme 1. Phosphinoferrocene Amidosulfonates $1^{\mathrm{R}}$ and $2^{R}$
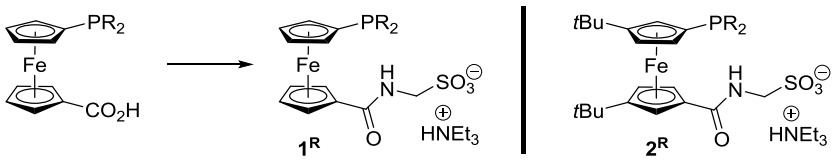

In this paper, we report the synthesis of new 
Lorsqu'un écrit scientifique issu d'une activité de recherche financée au moins pour moitié par des dotations de l'État, des collectivités territoriales ou des établissements publics, par des subventions d'agences de financement nationales ou par des fonds de l'Union européenne est publié dans un périodique paraissant au moins une fois par an, son auteur dispose, même après avoir accordé des droits exclusifs à un éditeur, du droit de mettre à disposition gratuitement dans un format ouvert, par voie numérique, sous réserve de l'accord des éventuels coauteurs, la version finale de son manuscrit acceptée pour publication, dès lors que l'éditeur met lui-même celle-ci gratuitement à disposition par voie numérique ou, à défaut, à l'expiration d'un délai courant à compter de la date de la première publication. Ce délai est au maximum de six mois pour une publication dans le domaine des sciences, de la technique et de la médecine et de douze mois dans celui des sciences humaines et sociales.

phosphinoferrocene amidosulfonate ligands $\mathbf{2}^{\mathbf{R}}$ containing bulky $t$-butyl substituents at the ferrocene scaffold (Scheme 1, right; $\mathrm{R}=\mathrm{Ph}, \mathrm{Cy}$ ). We have already shown that the introduction of sterically demanding $t$-butyl substituents to the ferrocene scaffold hinders rotation of the ferrocene cyclopentadienyls, thereby resulting in sterically locked conformations." Such conformations are beneficial for catalysis, ${ }^{12}$ partly because of preorganized strong interactions between the donor atoms. ${ }^{13}$ The aliphatic substituents also increase electron density at the ferrocene unit and at the attached phosphorus atom, and provide steric protection for the phosphine moiety and the ligated, catalytically active metal centre. Furthermore, aliphatic substituents render the phosphinoferrocene fragment more hydrophobic and can direct the ligated metal centres towards the organic components of the reaction system, typically the organic reagents. The hydrophilic amidosulfonate tags, meanwhile, can stabilize dispersions formed in water. ${ }^{4 c, 14}$ In this study, the effect of the additional auxiliary substituents was investigated in the challenging $\mathrm{Pd}$-catalysed $\mathrm{C}-\mathrm{H}$ arylation of unprotected indoles performed in water, using Pd-allyl complexes stabilized with ligands $\mathbf{1}^{\mathbf{R}}$ and $\mathbf{2}^{\mathbf{R}}$ as the precatalysts.

\section{RESULTS AND DISCUSSION}

Synthesis of Polar Phosphinoferrocenes and Their $\left(\eta^{3}\right.$-Allyl)palladium Complexes. The synthesis of planar-chiral but racemic phosphinoferrocene amidosulfonates $\mathbf{2}^{\mathbf{R}}$, where $\mathrm{R}=\mathrm{Ph}$ or cyclohexyl (Cy), was performed analogously to the synthesis of compounds $\mathbf{1}^{\mathbf{R}}$ lacking the $t$-butyl substituents (Scheme 2 ). The respective starting materials, phosphinocarboxylic acids $5^{\mathrm{R}}$, were obtained in two steps by sequential lithiation/functionalization of racemic $1,1^{\prime}$-dibromo-3,3'-di- $t$ butylferrocene $(3)^{15}$ via phosphine-bromides $4^{\mathrm{R}}$. Subsequent amidation producing compounds $2^{\mathrm{Ph}}$ and $2^{\mathrm{Cy}}$ was achieved by treating acids $5^{\mathrm{Ph}}$ and $5^{\mathrm{Cy}}$ successively with 1hydroxybenztriazole (HOBt), 1-ethyl-3-[3dimethylamino)propyl]carbodiimide (EDC), and aminomethanesulfonic acid in triethylamine/acetonitrile. ${ }^{9 c}$ This procedure furnished better yields of the coupling products, typically $\mathrm{ca}$. 95\% yield after chromatography than the method used previously to prepare $\mathbf{1}^{\mathbf{P h}}{ }^{6}$, in which the starting acids were converted to pentafluorophenyl esters that were subsequently reacted with aminomethanesulfonic acid and triethylamine.

Amide $\mathbf{2}^{\mathrm{Cy}}$ was also synthesized in its P-protected form (Scheme 2 ), $\mathbf{2}^{\mathrm{Cy}} \cdot \mathrm{BH}_{3}$. In this case, the amidation was performed with the protected acid $5^{\mathrm{Cy}} \cdot \mathrm{BH}_{3}$, obtained from $4^{\mathrm{Cy}} \cdot \mathrm{BH}_{3} \cdot{ }^{16}$ Deprotection was achieved by heating $\mathbf{2}^{\mathrm{Cy}} \cdot \mathrm{BH}_{3}$ in freshly distilled morpholine $\left(65^{\circ} \mathrm{C} / 16 \mathrm{~h}\right),{ }^{17}$ providing $2^{\mathrm{Cy}}$ in $66 \%$ yield after chromatography and crystallization. Although this route employs air-stable and easier-tohandle protected intermediates, it provides a lower overall yield of $2^{\mathrm{Cy}}$ than the shorter route, making use of unprotected intermediates (13\% vs. $38 \%$ ).

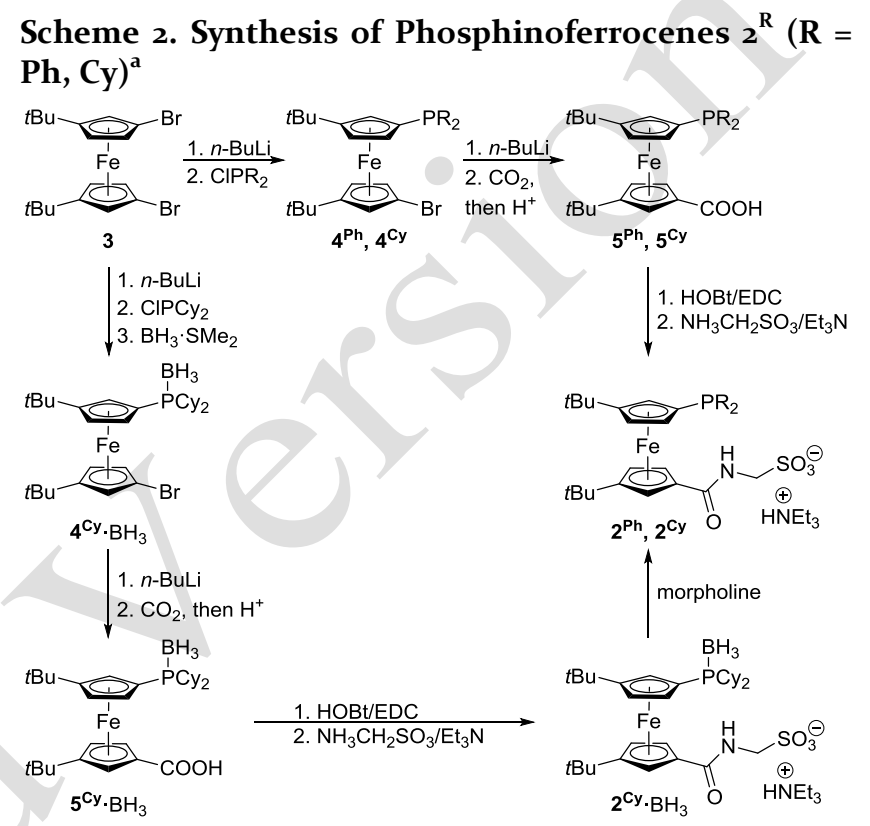

${ }^{\mathrm{a}} \mathrm{HOBt}=1$-hydroxybenzotriazole, $\mathrm{EDC}=1$-ethyl-3-[3dimethylamino)propyl]carbodiimide

Compounds $\mathbf{2}^{\mathrm{Ph}}$ and $\mathbf{2}^{\mathrm{Cy}}$ were purified by chromatography and crystallization from ethyl acetate, which removed minor amounts of the respective phosphine oxides. The compounds are orange crystalline materials, stable over extended periods, especially when stored under an inert atmosphere. In solution, they undergo slow oxidation under ambient conditions.

Polar ferrocenes $\mathbf{2}^{\mathbf{P h}}$ and $\mathbf{2}^{\mathrm{Cy}}$ and all reaction intermediates were characterized by NMR and IR spectroscopy, ESI mass spectrometry, and elemental analysis. The solidstate structures of $\mathbf{2}^{\mathbf{P h}}$ and $\mathbf{2}^{\mathrm{Cy}} \cdot \mathrm{BH}_{3}$ were determined by single-crystal X-ray diffraction analysis (Figure 1 and Table 1; additional structural diagrams are available as Supporting Information).

The molecular structure of $\mathbf{2}^{\mathrm{Ph}}$ (Figure 1 ) is similar to the structures of $\mathbf{1}^{\mathbf{P h}}$ and $\mathbf{1}^{\mathrm{Cy}_{\mathrm{y}}}$ reported earlier. ${ }^{6,9 \mathrm{C}}$ It comprises a regular ferrocene moiety, showing similar $\mathrm{Fe}-\mathrm{C}$ distances and negligible tilting. The functional substituents at positions 1 and $1^{\prime}$ depart by $20^{\circ}$ from an eclipsed arrangement. 

paraissant au moins une fois par an, son auteur dispose, même après avoir accordé des droits exclusifs à un éditeur, du droit de mettre à disposition gratuitement dans un format ouvert, par voie numérique, sous réserve de l'accord des éventuels coauteurs, la version finale de son manuscrit acceptée pour publication, dès lors que l'éditeur met lui-même celle-ci gratuitement à disposition par voie numérique ou, à défaut, à l'expiration d'un délai courant à compter de la date de la première publication. Ce délai est au maximum de six mois pour une publication dans le domaine des sciences, de la technique et de la médecine et de douze mois dans celui des sciences humaines et sociales.

The amide moiety is rotated by $16.5(3)^{\circ}$ with respect to its bonding cyclopentadienyl ring so that the nitrogen atom is inclined towards the ferrocene unit. In the crystal, the ions constituting the structure of $\mathbf{2}^{\mathrm{Ph}}$ assemble into closed arrays (Figure 1). Specifically, two amidosulfonate anions forming an enatiomeric pair are linked into dimers located around crystallographic inversion centres by pairs of $\mathrm{N}_{1}-\mathrm{H}_{1} \mathrm{~N} \ldots \mathrm{O}_{3}$ hydrogen bonds, and these dimers further serve as $\mathrm{H}$-bond acceptors for two adjacent $\mathrm{Et}_{3} \mathrm{NH}^{+}$ cations, with the latter acting as bifurcated $\mathrm{H}$-bond donors $\left(\mathrm{N}_{2}-\mathrm{H}_{2} \mathrm{~N} \cdots \mathrm{O}_{2} / \mathrm{N}_{2}-\mathrm{H}_{2} \mathrm{~N} \cdots \mathrm{O}_{4}\right)$.
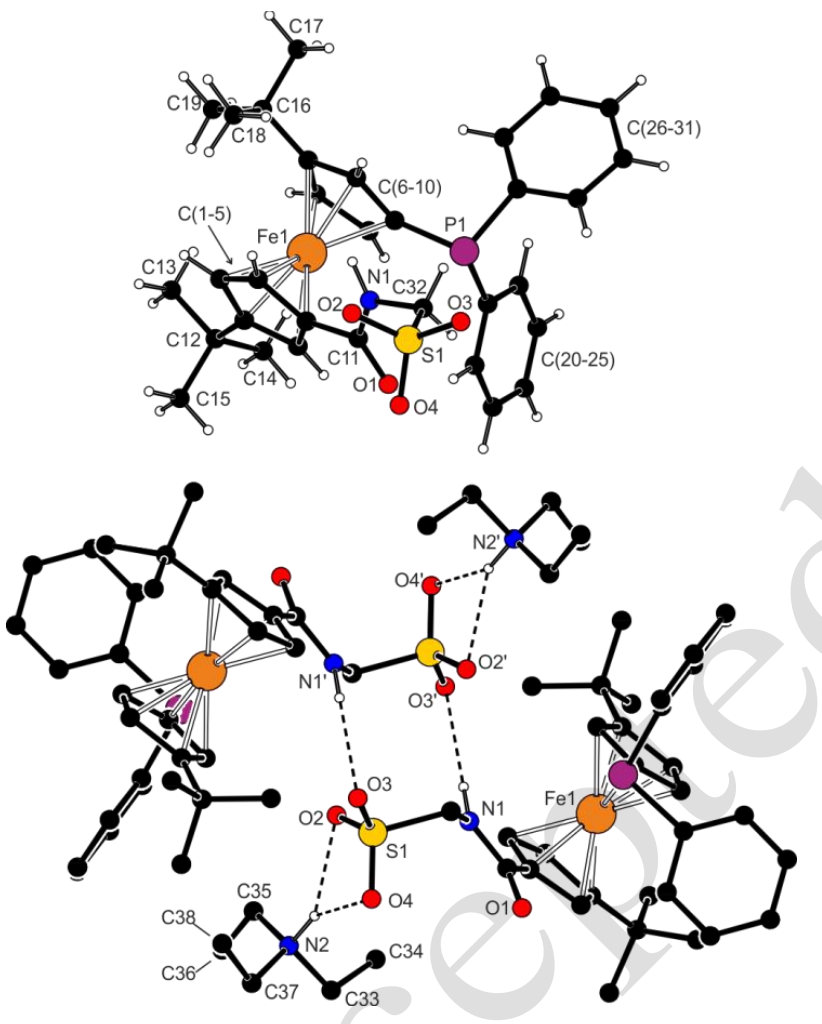

Figure 1. (top) View of the amidosulfonate anion in the structure of $\mathbf{2}^{\mathrm{Ph}}$ and (bottom) simplified packing diagram for the same compound. Hydrogen bond parameters: $\mathrm{N}_{1} \cdots \mathrm{O}_{3}=$ 3.289(3) $\AA, \mathrm{N}_{2} \cdots \mathrm{O}_{2}=3.096(3) \AA$, and $\mathrm{N}_{2} \cdots \mathrm{O}_{4}=2.794(3) \AA$. Note: only one position of the disordered atom $C_{37}$ is shown for clarity.

Table 1. Selected distances and angles for $2^{\mathrm{Ph}}$ and $2^{\mathrm{Cy}} \cdot \mathrm{BH}_{3}$ (in $\AA$ and $\mathrm{deg}$ )

$\begin{array}{ccc}\text { Parameter }^{\mathrm{a}} & 2^{\mathrm{Ph}} & 2^{\mathrm{Cy}} \cdot \mathrm{BH}_{3}\left(\mathrm{~mol} \mathrm{1} / \mathrm{mol} \mathrm{2}^{\mathrm{b}}\right. \\ \begin{array}{c}\text { Fe-C } \\ \text { (range) }\end{array} & 2.045(2)- & 2.037(5)-2.081(4) / 2.033(5)- \\ \text { tilt } & 2.080(2) & 2.085(4) \\ \tau & 1.3(1) & 4.2(3) / 3.9(3) \\ & 19.9(2) & 54.5(3) /-55.2(3)\end{array}$

$$
\begin{array}{ccc}
\mathrm{C}_{11}=\mathrm{O} 1 & 1.227(3) & 1.226(6) / 1.227(6) \\
\mathrm{C}_{11}-\mathrm{N}_{1} & 1.361(3) & 1.360(6) / 1.363(6) \\
\mathrm{N} 1-\mathrm{C}_{11}=\mathrm{O} 1 & 122.9(2) & 123.6(5) / 123.4(5) \\
\mathrm{S} 1-\mathrm{O} & 1.442(2)- & 1.453(4)-1.464(3) / 1.449(3)- \\
& 1.461(2) & 1.464(3) \\
\mathrm{C}_{32}-\mathrm{S}_{1} & 1.804(2) & 1.792(4) / 1.797(4)
\end{array}
$$

a Definitions: tilt is the dihedral angle between the leastsquares cyclopentadienyl planes; $\tau$ stands for the torsion angle $\mathrm{C}_{1}-\mathrm{Cg}_{1}-\mathrm{Cg}_{2}-\mathrm{C} 6$, where $\mathrm{Cg}_{1}$ and $\mathrm{Cg}_{2}$ denote the centroids of the cyclopentadienyl rings $C(1-5)$ and $C(6-10)$, respectively. ${ }^{b}$ Data for two structurally independent molecules. Further parameters: $\mathrm{P}_{1}-\mathrm{B}_{1}=1.919(6) / 1.924(6) \AA$.

Compound $2^{\mathrm{Cy}} \cdot \mathrm{BH}_{3}$ crystallizes with two structurally independent but essentially identical molecules (see Supporting Information). Its molecular structure is similar to ${ }_{2}{ }^{\mathbf{P h}}$. However, the ferrocene units adopt a more opened conformation (i.e., their substituents are more distant; see $\tau$ angles in Table 1 ), and the amide planes depart more from an arrangement coplanar with their parent cyclopentadienyl ring (dihedral angles: $34.0(6) / 35.5(6)^{\circ}$; in this case, the nitrogen atoms are diverted from the ferrocene unit). The crystal assembly of $2^{\mathrm{Cy}} \cdot \mathrm{BH}_{3}$ is virtually identical to that of $\mathbf{2}^{\mathrm{Ph}}$.

To examine the catalytic properties of $\mathbf{1}^{\mathbf{R}}$ and $\mathbf{2}^{\mathbf{R}}$, we used these hydrophilic ligands to prepare zwitterionic Pd(allyl) complexes applicable as defined pre-catalysts (Scheme 3).

Following the procedure used to prepare $6^{\mathrm{Cy}},{ }^{\mathrm{9c}}$ the ligands were first reacted with $\left[\mathrm{Pd}(\mu-\mathrm{Cl})\left(\eta^{3}-\mathrm{C}_{3} \mathrm{H}_{5}\right)\right]_{2}$ to give the nonisolated phosphine complexes $\left[\mathrm{PdCl}\left(\eta^{3}-\mathrm{C}_{3} \mathrm{H}_{5}\right)(\mathrm{L}-\kappa P)\right]$ $\left(\mathrm{L}=\mathbf{1}^{\mathbf{R}}\right.$ and $\left.\mathbf{2}^{\mathbf{R}}\right)$, which were treated with $\mathrm{Ag}\left[\mathrm{BF}_{4}\right]$ to remove the Pd-bound halide. The resulting zwitterionic complexes were less water soluble than the original phosphinoferrocenes. This was advantageously used during their purification: the partitioning of the crude product between $\mathrm{CH}_{2} \mathrm{Cl}_{2}$ and water removed $\left(\mathrm{Et}_{3} \mathrm{NH}\right)\left[\mathrm{BF}_{4}\right]$ and the subsequent flash chromatography and crystallization furnished pure complexes $6^{\mathrm{R}}$ and $7^{\mathrm{R}}$ as air-stable solids.

Scheme 3. Synthesis of Allylpalladium(II) Complexes $6^{\mathrm{R}}$ and $7^{\mathrm{R}}$ 
Lorsqu'un écrit scientifique issu d'une activité de recherche financée au moins pour moitié par des dotations de l'État, des collectivités territoriales ou des établissements publics, par des subventions d'agences de financement nationales ou par des fonds de l'Union européenne est publié dans un périodique paraissant au moins une fois par an, son auteur dispose, même après avoir accordé des droits exclusifs à un éditeur, du droit de mettre à disposition gratuitement dans un format ouvert, par voie numérique, sous réserve de l'accord des éventuels coauteurs, la version finale de son manuscrit acceptée pour publication, dès lors que l'éditeur met lui-même celle-ci gratuitement à disposition par voie numérique ou, à défaut, à l'expiration d'un délai courant à compter de la date de la première publication. Ce délai est au maximum de six mois pour une publication dans le domaine des sciences, de la technique et de la médecine et de douze mois dans celui des sciences humaines et sociales.

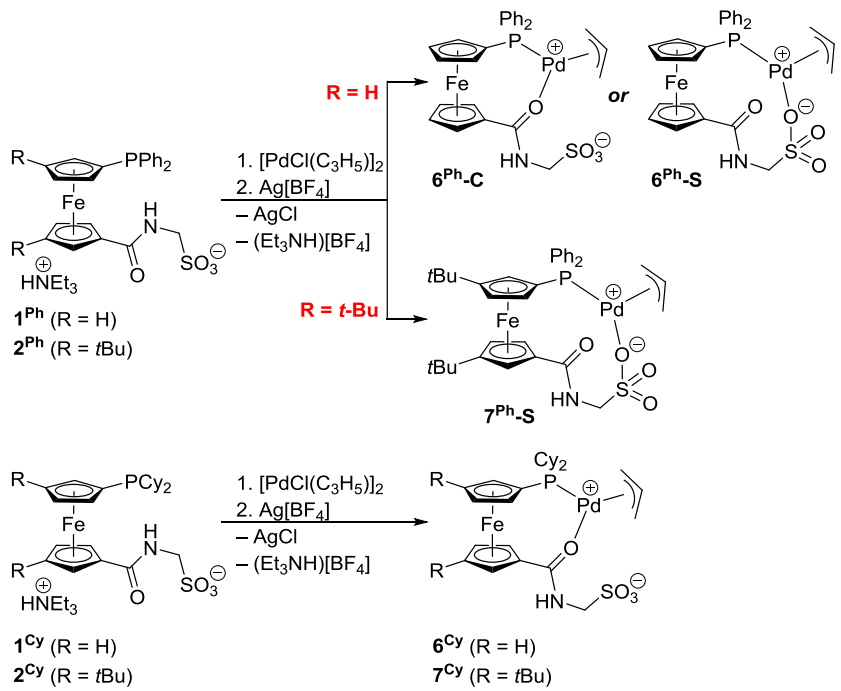

The ligands bearing dicyclohexylphosphine groups produced complexes $6^{\mathrm{Cy}}$ (reported compound ${ }^{\mathrm{c}}$ ) and $7^{\mathrm{Cy}}$, wherein the amide oxygen completed the coordination sphere of $\mathrm{Pd}(\mathrm{II})$ (N.B. for $7^{\mathrm{Cy}}$, the same product resulted upon crystallization from $\mathrm{CHCl}_{3}$ /hexane and $\mathrm{CH}_{2} \mathrm{Cl}_{2}+$ methanol/hexane). Conversely, depending on the crystallization conditions, complex $6^{\mathrm{Ph}}$ was isolated in two coordinative isomeric forms, where either the amide oxygen or the sulfonate oxygen coordinated to palladium (henceforth distinguished as $\mathbf{6}^{\mathrm{Ph}}-\mathbf{C}$ and $\left.\mathbf{6}^{\mathrm{Ph}}-\mathbf{S}\right)$. Whereas $\mathbf{6}^{\mathrm{Ph}}-\mathbf{C}$ containing a smaller and more rigid $\mathrm{P}, \mathrm{O}$-chelate ring was reproducibly obtained from the $\mathrm{CH}_{2} \mathrm{Cl}_{2}+$ metha$\mathrm{nol} /$ hexane mixture, the isomeric complex $6^{\mathrm{Ph}}-\mathrm{S}$ featuring a charge-supported $\mathrm{O} \rightarrow \mathrm{Pd}$ interaction resulted from crystallization with the $\mathrm{CHCl}_{3}$ /hexane mixture. Apparently, polar solvents that better solvate the charged sulfonate group favour the formation of $6^{\mathrm{Ph}}-\mathbf{C}$, whereas using a less polar solvent mixture leads to the preferential formation of $6^{\mathrm{Ph}}$-S. The analogous complex featuring $2^{\mathrm{Ph}}$ was isolated only as a $7^{\mathrm{Ph}}-\mathbf{S}$ isomer when employing either $\mathrm{CHCl}_{3}$ /ethyl acetate or $\mathrm{CH}_{2} \mathrm{Cl}_{2}+$ methanol/hexane mixtures for crystallization. The complexes were structurally authenticated by spectroscopic methods and by X-ray diffraction analysis (vide infra).

The formation of isomers differing by the coordination of the pendant amidosulfonate moiety was analysed by DFT. In particular, the differences in the Gibbs energy of the Cand S-isomers, $\Delta G=G_{\mathrm{S}}-G_{\mathrm{C}}$, at $298 \mathrm{~K}$ (Table 2) suggested that the isomer with the sulfonate-bound amidophosphine ligand is favoured for $7^{\mathrm{Ph}}$ in both $\mathrm{CHCl}_{3}$ and methanol. Conversely, the C-isomer is preferred for $7^{\mathrm{Cy}}$, in line with the experimental results. For complex $6^{\mathrm{Ph}}$, both isomers can be isolated depending on the crystallization conditions. The calculations favoured the $6^{\mathrm{Ph}}-\mathbf{S}$ isomer in
$\mathrm{CHCl}_{3}$ as the less polar solvent and revealed a slight preference for the $6^{\mathrm{Ph}}-\mathrm{C}$ isomer in methanol, again in accordance with the experimental observations. Although the PCM approach ${ }^{18}$ used for modelling the solvation effects has limitations for properly accounting for $\mathrm{H}$-bonding interactions, which seems to stabilize the C-isomers via solvation of the uncoordinated sulfonate moiety, our DFT results are consistent with the general experimental trends.

Table 2. Gibbs energy differences computed in $\mathrm{CHCl}_{3}$ and methanol (PCM) between the S- and C-isomers of $6^{\mathrm{Ph}}, 7^{\mathrm{Ph}}$, and $7^{\mathrm{Cy}}$

\begin{tabular}{cccc} 
Complex & \multicolumn{3}{r}{$\Delta G^{298}=G_{\mathrm{S}}{ }^{298}-G_{\mathrm{C}}{ }^{298}\left[\mathrm{kcal} \mathrm{mol}^{-1}\right]^{\mathrm{a}}$} \\
$\mathbf{6}^{\mathrm{Ph}}$ & vacuum & $\mathrm{CHCl}_{3}$ & methanol \\
$7^{\mathrm{Ph}}$ & -12.83 & -4.60 & 0.028 \\
$7^{\mathrm{Cy}}$ & 2.84 & -6.19 & -1.46 \\
& & 4.05 & 8.87
\end{tabular}

${ }^{\text {a }}$ Differences in Gibbs free energies at $298 \mathrm{~K}$. A negative $\Delta G$ value indicates that the $\mathrm{S}$-isomer is energetically favoured over the C-isomer; see Experimental for details. Full computational data are available in the Supporting Information.

Consistent with the solid-state results, the solution NMR spectra of $6^{\mathrm{R}}$ and $7^{\mathrm{R}}$ displayed markedly broad signals with significant temperature dependence. This indicated a net fluxionality of the complexes in solution, attributed to ligand shuttling (amide vs. sulfonate coordination) and rotation of the Pd-bound allyl moiety. FTIR spectra of the isomeric complexes were quite similar, differing mostly in band intensities. Nonetheless, some diagnostic differences could be observed in the region of carbon stretching modes (see Figure $\mathrm{S}_{1}$ ).

The structures of $\mathbf{6}^{\mathrm{Ph}}-\mathbf{C} \cdot \mathrm{CH}_{2} \mathrm{Cl}_{2} \cdot \mathrm{MeOH}$ and $\mathbf{6}^{\mathrm{Ph}}-\mathbf{S} \cdot \mathbf{1} .5 \mathrm{CHCl}$ are displayed in Figure 2; the structures of solvated $7^{\mathrm{Ph}}$ and $7^{\mathrm{Cy}}$ are reported in the Supporting Information, which also provides additional structural diagrams. As stated above, $\mathbf{6}^{\mathrm{Ph}}-\mathbf{C} \cdot \mathrm{CH}_{2} \mathrm{Cl}_{2} \cdot \mathrm{MeOH}$ and $\mathbf{6}^{\mathrm{Ph}}-\mathbf{S} \cdot \mathbf{1 .} \cdot 5 \mathrm{CHCl}_{3}$ differ in coordination of the amidosulfonate moiety. When comparing the molecular structures of $\mathbf{6}^{\mathrm{Ph}}-\mathbf{C}$ and $\mathbf{6}^{\mathrm{Ph}}-\mathbf{S}$ (Table 3 ), differences in the conformation of the 1,1'-disubstituted ferrocene units can be observed, with the pendant functions approximately $10^{\circ}$ closer in $6^{\mathrm{Ph}}-\mathbf{S}$. Twisting of the amide moiety in $6^{\mathrm{Ph}}-\mathrm{C}$ facilitates coordination of the amide oxygen $\mathrm{O}$, while in $6^{\mathrm{Ph}}-\mathrm{S}$, it brings the sulfonate group to the vicinity of the palladium atom (the dihedral angles of the amide plane and ring $\mathrm{C}(1-5)$ are $21.6(3)^{\circ}$ for $6^{\mathrm{Ph}}-\mathrm{C}$ and $8.8(2)^{\circ}$ in the opposite sense for $\left.6^{\mathrm{Ph}}-\mathrm{S}\right)$. In addition, coordination of $\mathrm{O}_{2}$ requires rotation of the sulfonate 
Lorsqu'un écrit scientifique issu d'une activité de recherche financée au moins pour moitié par des dotations de l'État, des collectivités territoriales ou des établissements publics, par des subventions d'agences de financement nationales ou par des fonds de l'Union européenne est publié dans un périodique paraissant au moins une fois par an, son auteur dispose, même après avoir accordé des droits exclusifs à un éditeur, du droit de mettre à disposition gratuitement dans un format ouvert, par voie numérique, sous réserve de l'accord des éventuels coauteurs, la version finale de son manuscrit acceptée pour publication, dès lors que l'éditeur met lui-même celle-ci gratuitement à disposition par voie numérique ou, à défaut, à l'expiration d'un délai courant à compter de la date de la première publication. Ce délai est au maximum de six mois pour une publication dans le domaine des sciences, de la technique et de la médecine et de douze mois dans celui des sciences humaines et sociales.

group along the pivotal $\mathrm{C}_{32}$-S1 bond. Despite these structural changes, the arrangement of the amidosulfonate chain remains similar ( $c f$. the torsion angles $\mathrm{C}_{11}-\mathrm{N}_{1}-\mathrm{C}_{32}-\mathrm{S}_{1}$ of $99.0(3)^{\circ}$ in $6^{\mathrm{Ph}}-\mathrm{C}$ and $95.4(2)^{\circ}$ in $\left.6^{\mathrm{Ph}}-\mathrm{S}\right)$. The difference in the ligand bite angles, $\mathrm{P}_{1}-\mathrm{Pd}_{1}-\mathrm{O}_{1}$ vs. $\mathrm{P}_{1}-\mathrm{Pd}_{1}-\mathrm{O}_{2}$, is also small $\left(\mathrm{ca} .5^{\circ}\right)$.

Another notable feature is the positioning of the amide oxygen $\mathrm{O}_{1}$ above the palladium atom in the molecule of $6^{\mathrm{Ph}}-\mathrm{S}\left(\mathrm{Pd}_{1} \cdots \mathrm{O}_{1}=2.888(1) \AA\right.$; the angle between the $\mathrm{Pd}_{1} \cdots \mathrm{O}_{1}$ interconnection and the $\left\{\mathrm{Pd}_{1}, \mathrm{P}_{1}, \mathrm{O}_{2}\right\}$ plane is $\left.77.88(5)^{\circ}\right)$, pointing to a possible "axial" interaction. ${ }^{19}$ No such contact is detected in the structure of $\mathbf{6}^{\mathbf{P h}}-\mathbf{C}$, where the shortest intramolecular distances between Pdı and sulfonate oxygen atoms exceed $5 \AA$. The allyl moiety in both structures is disordered over two positions that are approximately mirror images with respect to the $\{\mathrm{Pd}, \mathrm{O} n$, P1 $\}$ plane $(n=1$ or 2$)$.
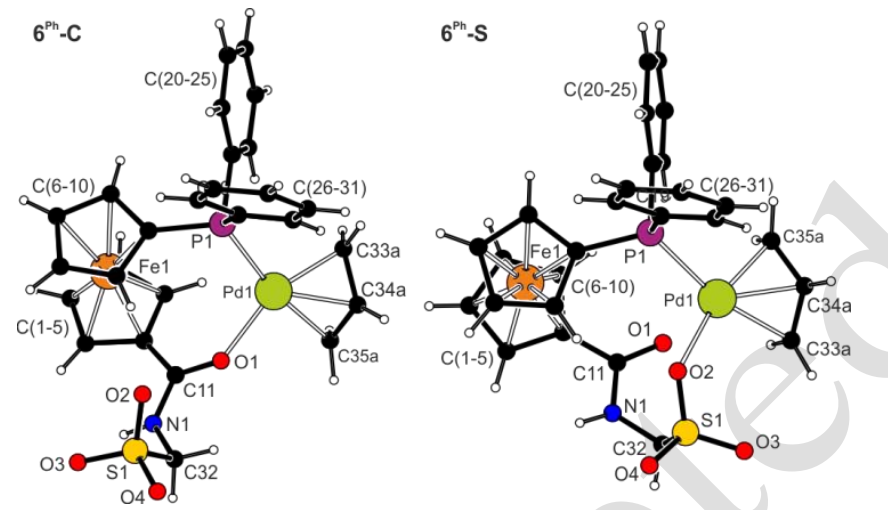

Figure 2. Views of the complex molecules in the structures of $6^{\mathbf{P h}}-\mathbf{C} \cdot \mathrm{CH}_{2} \mathrm{Cl}_{2} \cdot \mathrm{MeOH}$ and $\mathbf{6}^{\mathbf{P h}}-\mathbf{S} \cdot 1 \cdot 5 \mathrm{CHCl}_{3}$.

Table 3. Selected distances and angles for $6^{\mathrm{Ph}}$ $\mathrm{C} \cdot \mathrm{CH}_{2} \mathrm{Cl}_{2} \cdot \mathrm{MeOH}$ and $6^{\mathrm{Ph}}-\mathrm{S} \cdot 1.5 \mathrm{CHCl}_{3}$ (in $\AA$ and deg)

\begin{tabular}{ccc}
$\begin{array}{c}\text { Param- } \\
\text { eter }\end{array}$ & $\mathbf{6}^{\mathrm{Ph}}-\mathrm{C}(\mathrm{Y}=\mathrm{O} 1)$ & $\mathbf{6}^{\mathrm{Ph}}-\mathrm{S}\left(\mathrm{Y}=\mathrm{O}_{2}\right)$ \\
\hline $\mathrm{Pd} 1-\mathrm{P} 1$ & $2.3086(7)$ & $2.3189(7)$ \\
Pd1-Y & $2.123(2)$ & $2.165(1)$ \\
P1-Pd-Y & $101.11(6)$ & $96.16(3)$ \\
Fe1-C & $2.018(3)-2.075(3)$ & $2.024(2)-2.065(2)$ \\
tilt & $5.0(2)$ & $4.3(1)$ \\
$\tau$ & $59.3(2)$ & $49.4(1)$ \\
$\mathrm{C}_{11}=\mathrm{O} 1$ & $1.257(3)$ & $1.232(2)$ \\
$\mathrm{C}_{11}-\mathrm{N}_{1}$ & $1.336(4)$ & $1.357(2)$ \\
$\mathrm{N} 1-\mathrm{C}_{11}=\mathrm{O} 1$ & $120.4(2)$ & $122.6(2)$ \\
$\mathrm{S}_{1}-\mathrm{O} 2 / 3 / 4$ & $1.443(2) / 1.466(2) / 1.448($ & $1.478(1) / 1.451(1) / 1.449($
\end{tabular}

3)

1)

a Parameters are defined as for the free ligand; see footnote to Table 1.

Catalytic Experiments. Arylindoles are recurring motifs in biologically active molecules and pharmaceuticals. ${ }^{20}$ They have been prepared traditionally using crosscoupling strategies. ${ }^{21}$ However, the development of direct $\mathrm{C}-\mathrm{H}$ arylation, while challenging because of the intrinsic strength of this bond, allows direct functionalization of indoles, thus enabling simple synthesis of aryl-substituted indoles in a more atom-economic process. ${ }^{22}$ We used this reaction to assess the properties of palladium catalysts supported by polar ligands $\mathbf{1}^{\mathbf{R}}$ and $\mathbf{2}^{\mathbf{R}}$ (Scheme 4 ).

Scheme 4. Direct C-H Arylation of Unprotected Indoles using Allylpalladium Complexes $6^{\mathrm{R}}$ and $7^{\mathrm{R}}$

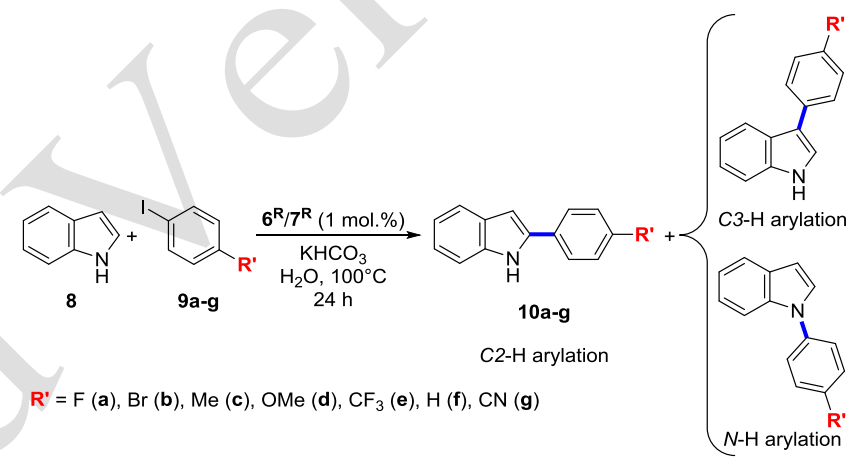

The arylation of unprotected indole $\mathbf{8}$ was performed in water using complexes $6^{\mathbf{R}}$ and $7^{\mathbf{R}}$ as defined pre-catalysts and various para-substituted iodoarenes as the arylating agents. Bromoarenes were found to be unreactive during preliminary reaction tests. The initial studies were conducted using 1 mol.\% $7^{\text {Ph }}$ for the reaction between 8 and 4-fluoro-1-iodobenzene (9a, Scheme 4). As shown in Table 4, the arylation proceeded with a high selectivity, producing nearly exclusively (>99\%) C2-arylated product 10a. We, however, take note of the challenges associated with this coupling reaction in biphasic conditions (see Experimental) since, despite our efforts, the best yields of arylated indoles were limited to $c a$. 50\%. As anticipated, the solvent played a crucial role. The use of classical organic solvents such as toluene, DMF, $\mathrm{AcOH}$, or dioxane (Table 4, entries 1-3 and 8) or alcohols (entries 6 and 7) and their more innocuous alternatives (ethylene carbonate and methyl cyclopentyl ether, entries 4 and 5) provided less than $5 \%$ conversion. We observed a $20 \%$ conversion using a 1:1 mixture of dioxane and water, albeit with a slight loss of selectivity (entry 9). Pleasingly, the use of pure water resulted in a better $25 \%$ conversion and full selectivity (entry 10). Gradually increasing the amount of catalyst $7^{\mathrm{Ph}}$ up to 5 mol.\% (entries 11 and 12) allowed us 
Lorsqu'un écrit scientifique issu d'une activité de recherche financée au moins pour moitié par des dotations de l'État, des collectivités territoriales ou des établissements publics, par des subventions d'agences de financement nationales ou par des fonds de l'Union européenne est publié dans un périodique paraissant au moins une fois par an, son auteur dispose, même après avoir accordé des droits exclusifs à un éditeur, du droit de mettre à disposition gratuitement dans un format ouvert, par voie numérique, sous réserve de l'accord des éventuels coauteurs, la version finale de son manuscrit acceptée pour publication, dès lors que l'éditeur met lui-même celle-ci gratuitement à disposition par voie numérique ou, à défaut, à l'expiration d'un délai courant à compter de la date de la première publication. Ce délai est au maximum de six mois pour une publication dans le domaine des sciences, de la technique et de la médecine et de douze mois dans celui des sciences humaines et sociales.

to improve this yield to $40 \%$ while conserving the $\mathrm{C}_{2}$ selectivity. Various bases other than $\mathrm{KHCO}_{3}$ were also tested, albeit with detrimental effects on either selectivity or on conversion, as illustrated for $\mathrm{K}_{2} \mathrm{CO}_{3}$ and KOAc (entries 13 and 14$)$.

Table 4. Screening of Conditions for the Pd-Catalysed Indole $\quad \mathrm{C}_{2}-\mathrm{H}$ Arylation Yielding 2(4Fluorophenyl)indole (1oa) ${ }^{\mathrm{a}}$

\begin{tabular}{|c|c|c|c|c|}
\hline Entry & Catalyst & Solvent & Base & $\begin{array}{l}\text { Yield of } \\
\text { 10a (\%) }\end{array}$ \\
\hline 1 & $7^{\mathrm{Ph}}(1 \%)$ & toluene & $\mathrm{KHCO}_{3}$ & $<1$ \\
\hline 2 & $7^{\mathrm{Ph}}(1 \%)$ & $\mathrm{DMF}$ & $\mathrm{KHCO}_{3}$ & $<1$ \\
\hline 3 & $7^{\mathrm{Ph}}(1 \%)$ & $\mathrm{AcOH}$ & $\mathrm{KHCO}_{3}$ & $<2$ \\
\hline 4 & $7^{\mathrm{Ph}}(1 \%)$ & $\begin{array}{l}\text { ethylene car- } \\
\text { bonate }\end{array}$ & $\mathrm{KHCO}_{3}$ & $<2$ \\
\hline 5 & $7^{\mathrm{Ph}}(1 \%)$ & $\mathrm{MeOC}_{5} \mathrm{H}_{9}$ & $\mathrm{KHCO}_{3}$ & $<2$ \\
\hline 6 & $7^{\mathrm{Ph}}(1 \%)$ & EtOH & $\mathrm{KHCO}_{3}$ & $<5$ \\
\hline 7 & $7^{\mathrm{Ph}}(1 \%)$ & $t$-amyl alcohol & $\mathrm{KHCO}_{3}$ & $<5$ \\
\hline 8 & $7^{\mathrm{Ph}}(1 \%)$ & dioxane & $\mathrm{KHCO}_{3}$ & $<5$ \\
\hline 9 & $7^{\mathrm{Ph}}(1 \%)$ & dioxane $/ \mathrm{H}_{2} \mathrm{O}^{\mathrm{b}}$ & $\mathrm{KHCO}_{3}$ & $20^{c}$ \\
\hline 10 & $7^{\mathrm{Ph}}(1 \%)$ & $\mathrm{H}_{2} \mathrm{O}$ & $\mathrm{KHCO}_{3}$ & 25 \\
\hline 11 & $7^{\text {Ph }}(3 \%)$ & $\mathrm{H}_{2} \mathrm{O}$ & $\mathrm{KHCO}_{3}$ & 29 \\
\hline 12 & $7^{\mathrm{Ph}}(5 \%)$ & $\mathrm{H}_{2} \mathrm{O}$ & $\mathrm{KHCO}_{3}$ & 40 \\
\hline 13 & $7^{\mathrm{Ph}}(1 \%)$ & $\mathrm{H}_{2} \mathrm{O}$ & $\mathrm{K}_{2} \mathrm{CO}_{3}$ & $15^{\mathrm{c}}$ \\
\hline 14 & $7^{\mathrm{Ph}}(1 \%)$ & $\mathrm{H}_{2} \mathrm{O}$ & KOAC & 11 \\
\hline
\end{tabular}

of dicyclohexylphosphino groups was also beneficial, and complex $7^{\mathrm{Cy}}$ provided $10 \mathrm{~b}$ in the best, albeit still modest yield of $19 \%$. This general trend was confirmed for the reactions producing $p$-tolyl derivative 1oc, since $7^{\mathrm{Cy}}$ provided $48 \%$ yield of this aryl indole (entry 11 ), while $7^{\mathrm{Ph}}$ achieved only $31 \%$ yield (entry 10), and the non-tbutylated counterparts $6^{\mathrm{Cy}}$ and $6^{\mathrm{Ph}}$ were found to be ineffective (entries 8 and 9).

Considering these results, the most active catalyst $7^{\mathrm{Cy}}$ was utilized in reaction tests employing iodoarenes $\mathbf{9 d - g}$ with different substituents. Thus, compounds 100 and 1oe, incorporating the 4-methoxyphenyl and 4(trifluoromethyl)phenyl moieties, were obtained in $47 \%$ and $40 \%$ yields (entries 12 and 13 ). The reaction of unsubstituted iodobenzene of proceeded with a lower conversion (36\% of 1of, entry 14), whereas arylation with its electron-poor cyano derivative $\mathbf{9 g}$ ( $15 \%$ of $\mathbf{1 0 g}$, entry 15 ) was more difficult. Surprisingly, catalyst $7^{\mathrm{cy}}$ showed a higher efficiency for electron-rich iodoarenes, which is rather unusual. ${ }^{22 b}$ Increasing the reaction time and the amount of catalysts had only marginal effects on the yield of the arylation product.

Table 5. Palladium-Catalysed $\mathrm{C}_{2}-\mathrm{H}$ Arylation of Indole using Substituted Iodoarenes $9 \mathrm{~b}-\mathrm{g}^{\mathrm{a}}$

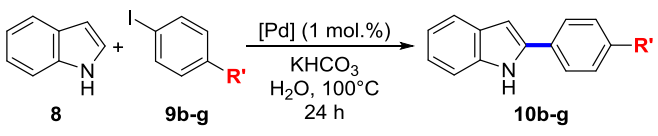

$\mathrm{R}^{\prime}=\mathrm{Br}(\mathbf{b}), \mathrm{Me}(\mathbf{c}), \mathrm{OMe}(\mathbf{d}), \mathrm{CF}_{3}(\mathbf{e}), \mathrm{H}(\mathbf{f}), \mathrm{CN}(\mathbf{g})$

\begin{tabular}{|c|c|c|c|c|}
\hline Entry & Catalyst & $\mathrm{R}^{\prime}$ & Product & $\begin{array}{c}\text { Yield } \\
(\%)\end{array}$ \\
\hline 1 & {$\left[\mathrm{PdCl}\left(\mathrm{C}_{3} \mathrm{H}_{5}\right)\right]_{2}$} & $\mathrm{Br}$ & lob & $<2$ \\
\hline 2 & {$\left[\mathrm{PdCl}\left(\mathrm{C}_{3} \mathrm{H}_{5}\right)\right]_{2} / \mathrm{PPh}_{3}$} & $\mathrm{Br}$ & 1ob & $<5$ \\
\hline 3 & {$\left[\mathrm{PdCl}\left(\mathrm{C}_{3} \mathrm{H}_{5}\right)\right]_{2} / \mathrm{PCy}_{3} \mathrm{HBF}_{4}$} & $\mathrm{Br}$ & lob & $<5$ \\
\hline 4 & $6^{\mathrm{Ph}}$ & $\mathrm{Br}$ & 1ob & 6 \\
\hline 5 & $6^{\mathrm{Cy}}$ & $\mathrm{Br}$ & 1ob & 12 \\
\hline 6 & $7^{\mathrm{Ph}}$ & $\mathrm{Br}$ & 1ob & 14 \\
\hline 7 & $7^{\mathrm{Cy}}$ & $\mathrm{Br}$ & 1ob & 19 \\
\hline 8 & $6^{\mathrm{Ph}}$ & $\mathrm{Me}$ & $10 \mathrm{C}$ & $<5$ \\
\hline 9 & $6^{\mathrm{Cy}}$ & $\mathrm{Me}$ & $10 \mathrm{c}$ & 7 \\
\hline 10 & $7^{\mathrm{Ph}}$ & $\mathrm{Me}$ & $10 \mathrm{c}$ & 31 \\
\hline 11 & $7^{\mathrm{Cy}}$ & $\mathrm{Me}$ & $10 \mathrm{c}$ & 48 \\
\hline 12 & $7^{\mathrm{Cy}}$ & OMe & $\operatorname{lod}$ & 47 \\
\hline 13 & $7^{\mathrm{Cy}}$ & $\mathrm{CF}_{3}$ & 1oe & 40 \\
\hline 14 & $7^{C y}$ & $\mathrm{H}$ & lof & 36 \\
\hline
\end{tabular}


Lorsqu'un écrit scientifique issu d'une activité de recherche financée au moins pour moitié par des dotations de l'État, des collectivités territoriales ou des établissements publics, par des subventions d'agences de financement nationales ou par des fonds de l'Union européenne est publié dans un périodique paraissant au moins une fois par an, son auteur dispose, même après avoir accordé des droits exclusifs à un éditeur, du droit de mettre à disposition gratuitement dans un format ouvert, par voie numérique, sous réserve de l'accord des éventuels coauteurs, la version finale de son manuscrit acceptée pour publication, dès lors que l'éditeur met lui-même celle-ci gratuitement à disposition par voie numérique ou, à défaut, à l'expiration d'un délai courant à compter de la date de la première publication. Ce délai est au maximum de six mois pour une publication dans le domaine des sciences, de la technique et de la médecine et de douze mois dans celui des sciences humaines et sociales.

$15 \quad 7^{\mathrm{Cy}} \quad \mathrm{CN} \quad \log \quad 15^{\mathrm{b}}$

${ }^{a}$ For conditions, see Table 3. The yields are from standardized ${ }^{1} \mathrm{H}$ NMR spectra and duplicate experiments. ${ }^{\mathrm{b}} \mathrm{A}$ loss of selectivity was observed with the formation of $c a$. $10 \%$ of arylated $\mathrm{C}_{3}$ isomer.

\section{CONCLUSION}

In this paper, we describe the synthesis of two new phosphinoferrocene ligands possessing hydrophilic amidosulfonate pendants and $t$-butyl substituents that limit the overall molecular mobility. Together with their analogues, which lack the $t$-butyl substituents, these compounds were used to prepare zwitterionic ( $\eta^{3}$-allyl)Pd(II) complexes. The formation of isomers differing by the coordination of the pendant amidosulfonate was noted, controlled by crystallization conditions. This behaviour, confirmed by the results of DFT calculations, underlines the hybrid nature of ligands $\mathbf{1}^{\mathbf{R}}$ and $\mathbf{2}^{\mathbf{R}}$, wherein the soft phosphine moiety forms a stronger bond to $\operatorname{Pd}(\mathrm{II})$ than the hard oxygen donors, which in turn results in fluxional coordination. As defined pre-catalysts, the allylpalladium complexes mediate direct $\mathrm{C}-\mathrm{H}$ arylation of indole with aryl iodides. Of note is the fairly low catalyst amount (1 mol.\%), high $\mathrm{C}_{2}$ selectivity, and the absence of the use of an additional phase-transfer agent in this catalytic system.

\section{EXPERIMENTAL SECTION}

Materials and Methods. All reactions were performed under an argon or nitrogen atmosphere by using standard Schlenk techniques. Racemic 1,1'-dibromo-3,3'-di-t-butylferrocene (3), $4^{\mathrm{Ph}, 5} 4^{\mathrm{Cy}} \cdot \mathrm{BH}_{3},{ }_{5} \mathrm{Cy} \cdot \mathrm{BH}_{3}, 5^{\mathrm{Ph}},{ }_{16} \mathbf{1}^{\mathbf{P h} 6}$, and $\mathbf{1}^{\mathrm{Cy} 9 \mathrm{c}}$ were prepared as previously reported. Anhydrous THF and dichloromethane were obtained from a Puresolv MD5 solvent purification system. Solvents used for chromatography and crystallizations were of reagent grade and were employed without additional purification. NMR spectra were recorded at $25^{\circ} \mathrm{C}$ on a Varian UNITY Inova 400, Bruker Avance 500 and 600 spectrometers. Chemical shifts $(\delta / \mathrm{ppm})$ are given relative to internal tetramethylsilane or, alternatively, to residual signals of the deuterated solvents $\left({ }^{1} \mathrm{H}\right.$ and ${ }^{13} \mathrm{C}$ NMR), and to external, $85 \%$ aqueous $\mathrm{H}_{3} \mathrm{PO}_{4}\left({ }^{3} \mathrm{P} \mathrm{NMR}\right)$. FTIR spectra were recorded on a Nicolet 6700 spectrometer in the range of $400-4000 \mathrm{~cm}^{-1}$. ESI mass spectra were obtained with a Bruker Compact Q-TOF spectrometer. Elemental analyses were performed using a Perkin-Elmer PE 2400 CHN analyser or a Thermo Electron Flash EA 1112 Series.

Synthesis of $4^{\mathrm{Cy}}$. Under an argon atmosphere, racemic 1,1'dibromo-3,3'-di-t-butylferrocene (3; $0.912 \mathrm{~g}, 2.0 \mathrm{mmol}$ ) was dissolved in dry THF (10 mL) in an oven-dried, two-necked reaction flask equipped with a stirring bar and an argon inlet. The solution was cooled with an acetone/liquid nitrogen bath to approximately $-80^{\circ} \mathrm{C}$ before $n$-butyllithium $(0.80 \mathrm{~mL}$ of $2.5 \mathrm{M}$ in hexanes, $2.0 \mathrm{mmol}$ ) was introduced, whereupon the initially yellow solution turned orange-red. The mixture was stirred and cooled for $30 \mathrm{~min}$, and then neat $\mathrm{ClPCy}_{2}$ (o.49 mL, $2.2 \mathrm{mmol}$ ) was added dropwise. The resulting mixture was stirred at $-80^{\circ} \mathrm{C}$ for another $30 \mathrm{~min}$ and then gradually warmed to room temperature over $90 \mathrm{~min}$. The crude reaction mixture was concentrated under reduced pressure, and the red oily residue was partitioned between dichloromethane and water (10 $\mathrm{mL}$ each). The organic phase was washed with brine, dried over magnesium sulfate and evaporated, leaving an orange oil, which was taken up with degassed pentane and transferred onto the top of a silica gel column packed in the same solvent. The first yellow band, removed by pentane and containing mostly bromo- and 1,1'-dibromo-3,3'-di-t-butylferrocene (8o $\mathrm{mg}$ ), was discarded, and the second major orange band eluted by degassed pentane/dichloromethane (4:1) was collected and evaporated, providing pure $4^{\mathrm{Cy}}$ as a yellow orange foam. Yield: $828 \mathrm{mg}(72 \%)$.

${ }^{1} \mathrm{H}$ NMR $\left(500 \mathrm{MHz}, \mathrm{CDCl}_{3}\right): \delta=4.29(\mathrm{dd}, J=2.4,1.3 \mathrm{~Hz}, 1 \mathrm{H}$, Cp), 4.15-4.13 (m, 1 H, Cp), $4.12(\mathrm{t}, J=1.5 \mathrm{~Hz}, 1 \mathrm{H}, \mathrm{Cp}), 4.03$ (dd, $J=$ $2.4,1.5 \mathrm{~Hz}, 1 \mathrm{H}, \mathrm{Cp}$ ), 3.92 (dd, $J=2.5,1.5 \mathrm{~Hz}, 1 \mathrm{H}, \mathrm{Cp}$ ), 3.79 (q, $J=$ $1.4 \mathrm{~Hz}, 1 \mathrm{H}, \mathrm{Cp}$ ), 2.00-1.63 (br m, $12 \mathrm{H}, \mathrm{Cy}$ ), 1.41-0.99 (br m, 10 H, Cy), $1.27(\mathrm{~s}, 9 \mathrm{H}, t \mathrm{Bu}), 1.22(\mathrm{~s}, 9 \mathrm{H}, t \mathrm{Bu}) \mathrm{ppm} .{ }^{13} \mathrm{C}\left\{{ }^{1} \mathrm{H}\right\}$ NMR $(126$ $\left.\mathrm{MHz}, \mathrm{CDCl}_{3}\right): \delta=105.06\left(\mathrm{~d}, J=2 \mathrm{~Hz}, \mathrm{C}^{\mathrm{ipso}}-t \mathrm{Bu}\right.$ of $\left.\mathrm{Cp}\right), 101.20$ $\left(C^{\text {ipso }}-t \mathrm{Bu}\right.$ of $\left.\mathrm{Cp}\right), 78.83$ (d, $J=19 \mathrm{~Hz}, \mathrm{C}^{\text {ipso }}-\mathrm{P}$ of $\mathrm{Cp}$ ), 78.71 ( $\mathrm{C}^{\mathrm{ipso}}$ $\mathrm{Br}), 73.10(\mathrm{~d}, J=14 \mathrm{~Hz}, \mathrm{CH}$ of $\mathrm{Cp}), 72.73(\mathrm{~d}, J=7 \mathrm{~Hz}, \mathrm{CH}$ of $\mathrm{Cp})$, $70.06(\mathrm{CH}$ of $\mathrm{Cp}), 69.45(\mathrm{~d}, J=2 \mathrm{~Hz}, \mathrm{CH}$ of $\mathrm{Cp}), 68.56(\mathrm{CH}$ of Cp), 64.58 (CH of Cp), 33.86 (d, J=13 Hz, Cy), 33.38 (d, $J=12 \mathrm{~Hz}$, $\mathrm{Cy}), 31.83\left(\mathrm{~d}, J=2 \mathrm{~Hz}, \mathrm{CH}_{3}\right.$ of $\left.t \mathrm{Bu}\right), 31.78\left(\mathrm{CH}_{3}\right.$ of $\left.t \mathrm{Bu}\right), 31.68\left(\mathrm{C}^{\text {ipso }}\right.$ $t \mathrm{Bu}), 31.56\left(\mathrm{C}^{\mathrm{ipso}} t \mathrm{Bu}\right), 30.95(\mathrm{Cy}), 30.81(\mathrm{~d}, J=14 \mathrm{~Hz}, \mathrm{Cy}), 30.71(\mathrm{~d}$, $J=10 \mathrm{~Hz}, \mathrm{Cy}), 30.70$ (Cy), 30.48 (d, $J=10 \mathrm{~Hz}, \mathrm{Cy}), 27.57$ (d, $J=11$ $\mathrm{Hz}, \mathrm{Cy}), 27.50$ (d, $J=10 \mathrm{~Hz}, \mathrm{Cy}), 27.47$ (Cy), 26.75 (Cy), 26.63 (Cy) ppm. ${ }^{31} \mathrm{P}\left\{{ }^{1} \mathrm{H}\right\}$ NMR $\left(202 \mathrm{MHz}, \mathrm{CDCl}_{3}\right): \delta=-8.8$ (s) ppm. FTIR (ATR diamond): $v_{\max }=2953 \mathrm{~m}, 2917 \mathrm{vs}, 2847 \mathrm{~s}, 1480 \mathrm{~m}, 1461 \mathrm{~m}$, $1446 \mathrm{~m}, 1381 \mathrm{~m}, 1358 \mathrm{~m}, 1297 \mathrm{w}, 1276 \mathrm{~m}, 1197 \mathrm{w}, 1174 \mathrm{~m}, 1074 \mathrm{w}$, $1045 \mathrm{~m}, 1022 \mathrm{w}, 997 \mathrm{w}, 917 \mathrm{~s}, 902, \mathrm{w}, 879 \mathrm{~s}, 843 \mathrm{~s}, 801 \mathrm{~m}, 747 \mathrm{w}$, $675 \mathrm{w}, 630 \mathrm{w}, 594 \mathrm{w}, 550 \mathrm{w}, 530 \mathrm{w}, 514 \mathrm{~s}, 497 \mathrm{vs}, 478 \mathrm{~s}, 445 \mathrm{~m}, 429$ $\mathrm{m} \mathrm{cm}^{-1}$. Anal. Calc. for $\mathrm{C}_{30} \mathrm{H}_{46} \mathrm{BrFeP}$ (573.4): $\mathrm{C} 62.84, \mathrm{H} 8.09 \%$. Found: C 63.09, H 7.92\%. ESI-MS: $m / z 573\left([\mathrm{M}+\mathrm{H}]^{+}\right)$.

Synthesis of $5^{\mathrm{Cy}}$. Compound $4^{\mathrm{Cy}}(0.470 \mathrm{~g}, 0.82 \mathrm{mmol})$ was dissolved in dry THF (10 mL) under an argon atmosphere. The solution was cooled in an acetone/liquid nitrogen bath to $-80^{\circ} \mathrm{C}$, and $n$-butyllithium ( $0.56 \mathrm{~mL}$ of $1.6 \mathrm{M}$ in hexanes, $0.90 \mathrm{mmol}$ ) was added with continuous stirring. The yellow solution turned orange-red after the addition. The resulting mixture was stirred at $-80^{\circ} \mathrm{C}$ for an additional $30 \mathrm{~min}$ before a stream of carbon dioxide was passed through the mixture, first at $-80^{\circ} \mathrm{C}$ for $2.5 \mathrm{~h}$ and then at room temperature for $30 \mathrm{~min}$. Then, the reaction mixture was diluted with dichloromethane $(5 \mathrm{~mL})$ and concentrated under reduced pressure. The oily residue was diluted by degassed $\mathrm{CH}_{2} \mathrm{Cl}_{2} / \mathrm{MeOH}$ (20:1) and transferred onto the top of a silica gel column packed with the same solvent. The first, minor yellow band was discarded and the following, major red band was collected and evaporated to afford acid $5^{\mathrm{Cy}}$ as a red-orange solid. Yield: $326 \mathrm{mg}$ (74\%).

${ }^{1} \mathrm{H}$ NMR (400 MHz, DMSO- $\left.d_{6}\right): \delta=12.07$ (br s, $1 \mathrm{H}, \mathrm{COOH}$ ), 4.59 (br s, 1 H, Cp), 4.35 (br s, 1 H, Cp), 4.21 (br s, 1 H, Cp), 4.09 (br s, 1 H, Cp), 4.05 (br s, 1 H, Cp), 3.88 (br s, 1 H, Cp), 1.95-1.53 (br m, $12 \mathrm{H}, \mathrm{Cy}$ ), 1.38-0.76 (br m, 10 H, Cy), 1.22 (s, $9 \mathrm{H}, t \mathrm{Bu}$ ), 1.20 (s, $9 \mathrm{H}, t \mathrm{Bu}$ ) ppm. ${ }^{13} \mathrm{C}\left\{{ }^{1} \mathrm{H}\right\}$ NMR (101 MHz, DMSO- $\left.d_{6}\right): \delta=172.16$ $(\mathrm{COOH}), 104.67\left(C^{\text {ipso }}-t \mathrm{Bu}\right.$ of $\left.\mathrm{Cp}\right), 104.20\left(\mathrm{~d}, J=3 \mathrm{~Hz}, \mathrm{C}^{\mathrm{ipso}}-t \mathrm{Bu}\right.$ of $\mathrm{Cp}), 77.41\left(\mathrm{~d}, J=21 \mathrm{~Hz}, \mathrm{C}^{\mathrm{ipso}}-\mathrm{P}\right.$ of $\left.\mathrm{Cp}\right), 71.46$ ( $C^{\text {ipso }}-\mathrm{COOH}$ of $\left.\mathrm{Cp}\right)$, 
Lorsqu'un écrit scientifique issu d'une activité de recherche financée au moins pour moitié par des dotations de l'État, des collectivités territoriales ou des établissements publics, par des subventions d'agences de financement nationales ou par des fonds de l'Union européenne est publié dans un périodique paraissant au moins une fois par an, son auteur dispose, même après avoir accordé des droits exclusifs à un éditeur, du droit de mettre à disposition gratuitement dans un format ouvert, par voie numérique, sous réserve de l'accord des éventuels coauteurs, la version finale de son manuscrit acceptée pour publication, dès lors que l'éditeur met lui-même celle-ci gratuitement à disposition par voie numérique ou, à défaut, à l'expiration d'un délai courant à compter de la date de la première publication. Ce délai est au maximum de six mois pour une publication dans le domaine des sciences, de la technique et de la médecine et de douze mois dans celui des sciences humaines et sociales.

71.01 (br s, CH of Cp), 70.07 (CH of $\mathrm{Cp}), 69.99(\mathrm{~d}, J \approx 14 \mathrm{~Hz}, \mathrm{CH}$ of $\mathrm{Cp}$ ), 69.09 ( $\mathrm{CH}$ of $\mathrm{Cp})$, 68.oo ( $\mathrm{CH}$ of $\mathrm{Cp}), 67.70(\mathrm{CH}$ of $\mathrm{Cp})$, $32.84(\mathrm{~d}, J=13 \mathrm{~Hz}, \mathrm{Cy}), 32.79(\mathrm{~d}, J=13 \mathrm{~Hz}, \mathrm{Cy}), 31.54(\mathrm{~d}, J=3 \mathrm{~Hz}$ $\mathrm{CH}_{3}$ of $\left.t \mathrm{Bu}\right), 31.26\left(\mathrm{CH}_{3}\right.$ of $\left.t \mathrm{Bu}\right), 31.03\left(\mathrm{C}^{\mathrm{ipso}}\right.$ of $\left.t \mathrm{Bu}\right), 30.89\left(\mathrm{C}^{\mathrm{ipso}}\right.$ of $t \mathrm{Bu}), 30.40(2 \times \mathrm{Cy}), 30.27(\mathrm{~d}, J=8 \mathrm{~Hz}, \mathrm{Cy}), 29.96(\mathrm{~d}, J=13 \mathrm{~Hz}$, Сy), 26.79 (Сy), 26.69 (2×Сy), 26.6o (Сy), 26.19 (Сy), 26.06 (Су) ppm. ${ }^{31} \mathrm{P}\left\{{ }^{1} \mathrm{H}\right\}$ NMR (162 MHz, DMSO- $\left.d_{6}\right): \delta=-10.2$ (s) ppm. The signal due to the corresponding phosphine oxide appears at $\delta_{\mathrm{P}}$ 45.2 (s). FTIR (ATR diamond): $v_{\max }=2957 \mathrm{~m}, 2918 \mathrm{~m}, 2850 \mathrm{~m}$ 1666 vs (CO), $1489 \mathrm{~m}, 1479 \mathrm{~m}, 1464 \mathrm{~m}, 1446 \mathrm{~m}, 1390 \mathrm{w}, 1366 \mathrm{~m}$, 1339 w, 1313 m, 1263 s, 1173 m, 1070 w, 1039 m, 1022 w, 996 w, 968 m, $939 \mathrm{~m}, 917 \mathrm{~m}, 885 \mathrm{w}, 852 \mathrm{~m}, 827 \mathrm{~m}, 818 \mathrm{~m}, 783 \mathrm{w}, 753 \mathrm{~m}, 676$ w, $630 \mathrm{w}, 614 \mathrm{~m}, 564 \mathrm{~m}, 532 \mathrm{~m}, 512 \mathrm{~m}, 499 \mathrm{~s}, 479 \mathrm{~m}, 441 \mathrm{~m} \mathrm{~cm}^{-1}$. Anal. Calc. for $\mathrm{C}_{31} \mathrm{H}_{47} \mathrm{FePO}_{2}$ (538.5): $\mathrm{C} 69.14, \mathrm{H}$ 8.80\%. Found: $\mathrm{C}$ 69.05, H 8.60\%. ESI-MS: $m / z 539\left([\mathrm{M}+\mathrm{H}]^{+}\right)$.

Synthesis of $2^{\mathrm{Ph}}$. Under argon, acid $5^{\mathrm{Ph}}(524.2 \mathrm{mg}$, $1.0 \mathrm{mmol})$ and 1-hydroxybenzotriazole (HOBt) $(162.1 \mathrm{mg}, 1.2 \mathrm{mmol})$ were suspended in a mixture of dry acetonitrile $(19 \mathrm{~mL})$ and triethylamine $(1.3 \mathrm{~mL})$. The mixture was cooled in an ice bath and treated with neat $N$-(3-dimethylaminopropyl)- $N^{\prime}$ ethylcarbodiimide) (EDC) $(0.2 \mathrm{~mL}, 1.2 \mathrm{mmol})$. After stirring at $4^{\circ} \mathrm{C}$ for $30 \mathrm{~min}$, solid aminomethanesulfonic acid $(888.0 \mathrm{mg}, 8.0$ $\mathrm{mmol}$ ) was added, and the mixture was stirred at room temperature for $24 \mathrm{~h}$. Then, it was filtered using a $0.45 \mu \mathrm{m}$ PTFE syringe filter and evaporated. The obtained crude product was purified by chromatography over a silica gel column using dichloromethane/methanol/triethylamine (90:9:1) as the eluent. The second band was collected and evaporated to give compound $\mathbf{2}^{\mathbf{P h}}$ as an orange solid. Yield: $686.3 \mathrm{mg}$ (95\%). Single crystals were obtained from $\mathrm{CH}_{2} \mathrm{Cl}_{2} /$ AcOEt.

${ }^{1} \mathrm{H}$ NMR ( $400 \mathrm{MHz}, \mathrm{CD}_{2} \mathrm{Cl}_{2}$ ): $\delta=9.86\left(\right.$ br s, $1 \mathrm{H}, \mathrm{HNEt}_{3}$ ), 7.63 7.55 (m, $2 \mathrm{H}, \mathrm{Ph}), 7.40-7.35(\mathrm{~m}, 3 \mathrm{H}, \mathrm{Ph}), 7.27-7.16(\mathrm{~m}, 5 \mathrm{H}, \mathrm{Ph})$, 6.59 (m, 1 H, NHCO), 4.66 (dd, $\left.J=13.4,8.1 \mathrm{~Hz}, 1 \mathrm{H}, \mathrm{CH}_{2}\right), 4.58$ (dd, $J=2.6,1.4 \mathrm{~Hz}, 1 \mathrm{H}, \mathrm{Cp}), 4.37(\mathrm{t}, J=1.5 \mathrm{~Hz}, 1 \mathrm{H}, \mathrm{Cp}), 4.20(\mathrm{dd}$, $J=2.4,1.5 \mathrm{~Hz}, 1 \mathrm{H}, \mathrm{Cp}$ ), 4.18 (dd, $J=2.6,1.5 \mathrm{~Hz}, 1 \mathrm{H}, \mathrm{Cp}), 4.15$ (dt, $J$ $=2.8,1.5 \mathrm{~Hz}, 1 \mathrm{H}, \mathrm{Cp}), 4.14\left(\mathrm{dd}, J=13.4,4.8 \mathrm{~Hz}, 1 \mathrm{H}, \mathrm{CH}_{2}\right), 3.95$ (dt, $J=2.6,1.3 \mathrm{~Hz}, 1 \mathrm{H}, \mathrm{Cp}), 3.07(\mathrm{dq}, J=7.2,3.2 \mathrm{~Hz}, 6 \mathrm{H}$, $\left.\mathrm{CH}_{3} \mathrm{CH}_{2} \mathrm{~N}\right), 1.27\left(\mathrm{t}, J=1.3 \mathrm{~Hz}, 9 \mathrm{H}, \mathrm{CH}_{3} \mathrm{CH}_{2} \mathrm{~N}\right), 1.27(\mathrm{~s}, 9 \mathrm{H}, t \mathrm{Bu})$, $0.99(\mathrm{~s}, 9 \mathrm{H}, t \mathrm{Bu}) \mathrm{ppm} .{ }^{13} \mathrm{C}\left\{{ }^{1} \mathrm{H}\right\} \mathrm{NMR}\left(101 \mathrm{MHz}, \mathrm{CD}_{2} \mathrm{Cl}_{2}\right): \delta=170.0$ $(\mathrm{CONH}), 141.0\left(\mathrm{~d},{ }^{1} J_{\mathrm{PC}}=12 \mathrm{~Hz}, \mathrm{C}^{\mathrm{ipso}}\right.$ of $\left.\mathrm{Ph}\right), 138.1\left(\mathrm{~d},{ }^{1} J_{\mathrm{PC}}=10 \mathrm{~Hz}\right.$, $\mathrm{C}^{\text {ipso }}$ of $\left.\mathrm{Ph}\right), 135.5(\mathrm{~d}, J=22 \mathrm{~Hz}, \mathrm{CH}$ of $\mathrm{Ph}), 132.7(\mathrm{~d}, J=19 \mathrm{~Hz}, \mathrm{CH}$ of $\mathrm{Ph}), 129.7\left(\mathrm{CH}^{\text {para }}\right.$ of $\left.\mathrm{Ph}\right), 128.9(\mathrm{~d}, J=8 \mathrm{~Hz}, \mathrm{CH}$ of $\mathrm{Ph}), 128.6(\mathrm{~d}$, $J=6 \mathrm{~Hz}, \mathrm{CH}$ of $\mathrm{Ph}), 128.4\left(\mathrm{CH}^{\text {para }}\right.$ of $\left.\mathrm{Ph}\right), 107.3\left(\mathrm{~d}, J=6 \mathrm{~Hz}, \mathrm{C}^{\text {ipso }}\right.$ $t \mathrm{Bu}$ of $\mathrm{Cp}), 105.6\left(\mathrm{C}^{\mathrm{ipso}}-t \mathrm{Bu}\right.$ of $\left.\mathrm{Cp}\right), 76.1\left(\mathrm{~d},{ }^{1} \mathrm{~J}_{\mathrm{PC}}=7 \mathrm{~Hz}, \mathrm{C}^{\mathrm{ipso}}-\mathrm{P}\right.$ of Cp), 75.5 ( $C^{\text {ipso }}-\mathrm{CONH}$ of $\left.\mathrm{Cp}\right), 73.6(\mathrm{~d}, J=25 \mathrm{~Hz}, \mathrm{CH}$ of $\mathrm{Cp}), 71.7$ (CH of $\mathrm{Cp}$ ), 69.7 ( $\mathrm{CH}$ of $\mathrm{Cp}$ ), 69.05 ( $\mathrm{CH}$ of $\mathrm{Cp}$ ), 68.95 ( $\mathrm{CH}$ of $\mathrm{Cp}$ ), $67.2(\mathrm{~d}, J=3 \mathrm{~Hz}, \mathrm{CH}$ of $\mathrm{Cp}),{ }_{5} 6.1\left(\mathrm{CH}_{2} \mathrm{SO}_{3}\right), 46.5\left(\mathrm{CH}_{3} \mathrm{CH}_{2} \mathrm{~N}\right), 31.7$ ( $\mathrm{CH}$ of $t \mathrm{Bu}), 31.5(\mathrm{CH}$ of $t \mathrm{Bu}), 31.2\left(\mathrm{C}^{\mathrm{ipso}}\right.$ of $\left.t \mathrm{Bu}\right), 30.7\left(\mathrm{C}^{\mathrm{ipso}}\right.$ of $t \mathrm{Bu}), 8.8\left(\mathrm{CH}_{3} \mathrm{CH}_{2} \mathrm{~N}\right)$ ppm. ${ }^{31} \mathrm{P}\left\{{ }^{1} \mathrm{H}\right\}$ NMR $\left(162 \mathrm{MHz}, \mathrm{CD}_{2} \mathrm{Cl}_{2}\right): \delta=-$ $18.4(\mathrm{~s})$ ppm. FTIR (Nujol): $v_{\max }=3335 \mathrm{w}(\mathrm{N}-\mathrm{H}), 3051 \mathrm{~m}(\mathrm{~N}-\mathrm{H})$, $2720 \mathrm{w}, 2688 \mathrm{w}, 2525 \mathrm{w}, 2360 \mathrm{w}, 2342 \mathrm{w}, 1717 \mathrm{w}, 1656 \mathrm{~s}(\mathrm{C}=\mathrm{O})$, $1585 \mathrm{w}, 1569 \mathrm{w}, 1532 \mathrm{~m}, 1316 \mathrm{w}, 1299 \mathrm{w}, 1262 \mathrm{~m}, 1212 \mathrm{~m}, 1175 \mathrm{~m}$ $(\mathrm{S}=\mathrm{O}), 1153 \mathrm{~m}$ (P-C), $1104 \mathrm{w}, 1087 \mathrm{w}, 1079 \mathrm{w}, 1071 \mathrm{w}, 1036 \mathrm{~s}(\mathrm{~S}=\mathrm{O})$, $971 \mathrm{w}(\mathrm{P}-\mathrm{C}), 930 \mathrm{w}, 918 \mathrm{w}, 907 \mathrm{w}, 895 \mathrm{w}, 876 \mathrm{w}, 864 \mathrm{w}, 849 \mathrm{w}$, $830 \mathrm{w}, 813 \mathrm{w}, 766 \mathrm{w}, 751 \mathrm{~m}, 743 \mathrm{~m}, 699 \mathrm{~m}, 675 \mathrm{w}, 669 \mathrm{w}, 626 \mathrm{w}$, $607 \mathrm{~m}, 539 \mathrm{~m}, 530 \mathrm{~m}, 514 \mathrm{~m}, 497 \mathrm{~m}, 479 \mathrm{~m}, 464 \mathrm{w}, 442 \mathrm{~m}, 424 \mathrm{~m}$, $411 \mathrm{~m} \mathrm{~cm}^{-1}$. Anal. Calc. for $\mathrm{C}_{38} \mathrm{H}_{53} \mathrm{~N}_{2} \mathrm{PO}_{4} \mathrm{FeS}$ (720.28): $\mathrm{C} 63.33, \mathrm{H}$ 7.41, N 3.89\%. Found: C 63.03, H 7.15, N 4.05\%. ESI-MS: $\mathrm{m} / \mathrm{z} 618$ $\left(\left[\mathrm{M}-\mathrm{HNEt}_{3}\right]^{-}\right)$.
Synthesis of $2^{\mathrm{Cy}}$. An oven-dried, two-necked flask equipped with an argon inlet and stirring bar was charged with acid $\mathbf{5}^{\mathrm{Cy}_{\mathrm{y}}}$ (619 $\mathrm{mg}, 1.15 \mathrm{mmol})$ and HOBt $(212 \mathrm{mg}, 1.38 \mathrm{mmol})$, flushed with argon, and sealed. The solids were dissolved by adding dry acetonitrile $(20 \mathrm{~mL})$ and degassed triethylamine $(8 \mathrm{~mL})$. The solution was cooled on ice, before neat EDC (o.24 mL, $1.38 \mathrm{mmol})$ was introduced, followed by solid aminomethanesulfonic acid $(1.022 \mathrm{~g}, 9.20 \mathrm{mmol})$. The reaction mixture was stirred at room temperature for $24 \mathrm{~h}$ and then evaporated. The solid residue was taken up with a dichloromethane/methanol/triethylamine (95:4:1) mixture and transferred onto the top of a silica gel column. Elution with the same solvent mixture led to the development of a pale orange band, which was discarded, and a major orange band, which was collected and evaporated. The oily residue was dissolved in hot ethyl acetate $(5 \mathrm{~mL})$ and crystallized by cooling to $4^{\circ} \mathrm{C}$. The separated orange crystalline solid was isolated by suction and dried under vacuum. Yield of $2^{\mathrm{Cy}}: 596 \mathrm{mg}$ (71\%).

${ }^{1} \mathrm{H}$ NMR (40o MHz, DMSO- $\left.d_{6}\right): \delta=9.29\left(\right.$ br s, $1 \mathrm{H}, H \mathrm{NEt}_{3}$ ), 7.74 (dd, $J=7.7,5.0 \mathrm{~Hz}, 1 \mathrm{H}, \mathrm{NHCO}), 4.86(\mathrm{dd}, J=2.6,1.4 \mathrm{~Hz}, 1 \mathrm{H}$, Cp), $4.55(\mathrm{t}, J=1.5 \mathrm{~Hz}, 1 \mathrm{H}, \mathrm{Cp}), 4.26(\mathrm{dd}, J=13.0,7.6 \mathrm{~Hz}, 1 \mathrm{H}$, $\left.\mathrm{CHSO}_{3}\right), 4.22(\mathrm{dd}, J=2.5,1.6 \mathrm{~Hz}, 1 \mathrm{H}, \mathrm{Cp}), 4.15-4.13(\mathrm{~m}, 1 \mathrm{H}, \mathrm{Cp})$, $4.00(\mathrm{dd}, J=2.5,1.6 \mathrm{~Hz}, 1 \mathrm{H}, \mathrm{Cp}), 3.84$ (q, $J=1.5 \mathrm{~Hz}, 1 \mathrm{H}, \mathrm{Cp}), 3.79$ $\left(\mathrm{dd}, J=13.0,4.9 \mathrm{~Hz}, 1 \mathrm{H}, \mathrm{CHSO}_{3}\right), 3.08(\mathrm{q}, J=7.3 \mathrm{~Hz}, 6 \mathrm{H}$, $\left.\mathrm{CH}_{3} \mathrm{CH}_{2} \mathrm{~N}\right), 2.10-2.20(\mathrm{~m}, 1 \mathrm{H}, \mathrm{Cy}), 1.95-0.85(\mathrm{~m}, 2 \mathrm{OH}, \mathrm{Cy}), 1.21$ $(\mathrm{s}, 9 \mathrm{H}, t \mathrm{Bu}), 1.18\left(\mathrm{t}, J=7.3 \mathrm{~Hz}, 9 \mathrm{H}, \mathrm{CH}_{3} \mathrm{CH}_{2} \mathrm{~N}\right), 1.17(\mathrm{~s}, 9 \mathrm{H}, t \mathrm{Bu})$, $0.68-0.55(\mathrm{~m}, 1 \mathrm{H}, \mathrm{Cy}) \mathrm{ppm} .{ }^{13} \mathrm{C}\left\{{ }^{1} \mathrm{H}\right\}$ NMR (101 MHz, DMSO- $\left.d_{6}\right)$ : $\delta=168.45(\mathrm{CONH}), 104.46\left(\mathrm{~d}, J=4 \mathrm{~Hz}, \mathrm{C}^{\mathrm{ipso}}-t \mathrm{Bu}\right.$ of $\left.\mathrm{Cp}\right), 103.76$ $\left(C^{\text {ipso }}-t\right.$ Bu of $\left.C \mathrm{p}\right), 76.11\left(\mathrm{~d}, J=20 \mathrm{~Hz}, C^{\text {ipso }}-\mathrm{P}\right.$ of $\left.C \mathrm{p}\right), 75.59\left(C^{\mathrm{ipso}}-\right.$ CONH of Cp), 70.39 (d, J = 20 Hz, CH of Cp), 69.46 (CH of Cp), 69.30 ( $\mathrm{CH}$ of $\mathrm{Cp}$ ), 68.72 ( $\mathrm{CH}$ of $\mathrm{Cp}$ ), 67.50 ( $\mathrm{CH}$ of $\mathrm{Cp}$ ), $66.29(\mathrm{CH}$ of $\mathrm{Cp}), 55.50\left(\mathrm{CH}_{2} \mathrm{SO}_{3}\right), 45.65\left(\mathrm{CH}_{3} \mathrm{CH}_{2} \mathrm{~N}\right), 33.28(\mathrm{~d}, J=15 \mathrm{~Hz}, \mathrm{Cy})$, $32.38(\mathrm{~d}, J=12 \mathrm{~Hz}, \mathrm{Cy}), 31.79\left(\mathrm{~d}, J=3 \mathrm{~Hz}, \mathrm{CH}_{3}\right.$ of $\left.t \mathrm{Bu}\right), 31.55\left(\mathrm{C}^{\mathrm{ipso}}\right.$ of $\mathrm{tBu}), 31.50\left(\mathrm{CH}_{3}\right.$ of $\left.t \mathrm{Bu}\right), 31.37\left(\mathrm{C}^{\mathrm{ips}}\right.$ of $\left.\mathrm{tBu}\right), 30.73(\mathrm{~d}, J=17 \mathrm{~Hz}$, Cy), 30.38 (Cy), 30.29 (Cy), 29.38 (d, $J=10.5 \mathrm{~Hz}, \mathrm{Cy}), 28.69$ (br s, Cy), 27.01 (d, $J=4 \mathrm{~Hz}, \mathrm{Cy}), 26.89$ (d, $J=5 \mathrm{~Hz}, \mathrm{Cy}), 26.69$ (d, $J=8$ $\mathrm{Hz}, \mathrm{Cy}), 26.62$ (d, $J=6 \mathrm{~Hz}, \mathrm{Cy}), 26.21(\mathrm{Cy}), 26.10(\mathrm{Cy}), 8.57$ $\left(\mathrm{CH}_{3} \mathrm{CH}_{2} \mathrm{~N}\right)$ ppm. ${ }^{31} \mathrm{P}\left\{{ }^{1} \mathrm{H}\right\}$ NMR $\left(162 \mathrm{MHz}, \mathrm{DMSO}-d_{6}\right): \delta=-10.0(\mathrm{~s})$ $\mathrm{ppm}$. The signal of the respective phosphine oxide is observed at $\delta_{\mathrm{P}} 45.2(\mathrm{~s})$. FTIR (ATR diamond): $v_{\max }=3345 \mathrm{w}, 3082 \mathrm{w}, 2915 \mathrm{~m}$, $2848 \mathrm{~m}, 2696 \mathrm{w}, 1651 \mathrm{~m}$ (CO), $1522 \mathrm{~m}, 1484 \mathrm{~m}, 1449 \mathrm{~m}, 390 \mathrm{w}$, $1363 \mathrm{w}, 1313 \mathrm{w}, 1256 \mathrm{~m}, 1233 \mathrm{~m}, 1209 \mathrm{~m}, 1163$ s, 1075 w, 1035 s, 969 w, 930 w, 919 w, 897 w, 848 m, 814 w, 791 w, 772 w, 750 w, 669 w, $598 \mathrm{~m}, 532 \mathrm{~m}, 519 \mathrm{~m}, 487 \mathrm{~m}, 441 \mathrm{w} \mathrm{cm}^{-1}$. Anal. Calc. for $\mathrm{C}_{38} \mathrm{H}_{65} \mathrm{~N}_{2} \mathrm{FeO}_{4} \mathrm{PS}$ (732.8): C 62.28, $\mathrm{H}$ 8.94, $\mathrm{N} 3.82 \%$. Found: $\mathrm{C}$ 61.90, H 8.68, N 3.65\%. ESI-MS: $m / z 630\left(\left[\mathrm{M}-\mathrm{HNEt}_{3}\right]^{-}\right)$.

Synthesis of $2^{\mathrm{Cy}_{1}} \cdot \mathrm{BH}_{3}$. Compound $2^{\mathrm{C}_{\mathrm{y}}} \cdot \mathrm{BH}_{3}$ was prepared similarly, starting from $5^{\mathrm{Cy}} \cdot \mathrm{BH}_{3}(1.10 \mathrm{~g}, 2.0 \mathrm{mmol})$ and HOBt $(0.324 \mathrm{~g}$, $2.4 \mathrm{mmol})$ in dry acetonitrile $(38 \mathrm{~mL})$ and triethylamine $(2.6$ $\mathrm{mL}$ ). The suspension was cooled in an ice bath and treated with neat EDC (o.40 mL, $2.4 \mathrm{mmol})$. The mixture was stirred at $0^{\circ} \mathrm{C}$ for $30 \mathrm{~min}$, and aminomethanesulfonic acid $(1.78 \mathrm{~g}, 16.0 \mathrm{mmol})$ was added. The resultant mixture was stirred at room temperature for $24 \mathrm{~h}$ and filtered through a $0.45 \mu \mathrm{m}$ PTFE syringe filter, and the filtrate was evaporated. The crude product was purified by chromatography over silica gel and eluted with a dichloromethane/methanol/triethylamine mixture (90:9:1). The main second band was collected and evaporated, leaving $2^{\mathrm{Cy}} \cdot \mathbf{B H}_{3}$ as an 
Lorsqu'un écrit scientifique issu d'une activité de recherche financée au moins pour moitié par des dotations de l'État, des collectivités territoriales ou des établissements publics, par des subventions d'agences de financement nationales ou par des fonds de l'Union européenne est publié dans un périodique paraissant au moins une fois par an, son auteur dispose, même après avoir accordé des droits exclusifs à un éditeur, du droit de mettre à disposition gratuitement dans un format ouvert, par voie numérique, sous réserve de l'accord des éventuels coauteurs, la version finale de son manuscrit acceptée pour publication, dès lors que l'éditeur met lui-même celle-ci gratuitement à disposition par voie numérique ou, à défaut, à l'expiration d'un délai courant à compter de la date de la première publication. Ce délai est au maximum de six mois pour une publication dans le domaine des sciences, de la technique et de la médecine et de douze mois dans celui des sciences humaines et sociales.

orange solid. Yield: $1.42 \mathrm{~g}(95 \%)$. Single crystals were obtained from $\mathrm{CH}_{2} \mathrm{Cl}_{2} / \mathrm{AcOEt}$.

${ }^{1} \mathrm{H}$ NMR (40o $\left.\mathrm{MHz}, \mathrm{CD}_{2} \mathrm{Cl}_{2}\right): \delta=6.62-6.58(\mathrm{~m}, 1 \mathrm{H}, \mathrm{NH}), 4.75$ (dd, $J=2.6,1.4 \mathrm{~Hz}, 1 \mathrm{H}, \mathrm{Cp}), 4.67(\mathrm{t}, J=1.5 \mathrm{~Hz}, 1 \mathrm{H}, \mathrm{Cp}), 4.58$ (dd, $\left.J=13.5,7.5 \mathrm{~Hz}, 1 \mathrm{H}, \mathrm{CH}_{2}\right), 4.40-4.37(\mathrm{~m}, 1 \mathrm{H}, \mathrm{Cp}), 4.35(\mathrm{dd}, J=2.6$, $1.6 \mathrm{~Hz}, 1 \mathrm{H}, \mathrm{Cp}), 4.31-4.29$ (m, $1 \mathrm{H}, \mathrm{Cp}), 4.23$ (dd, $J=13.5,5.5 \mathrm{~Hz}, 1$ $\mathrm{H}, \mathrm{CH}_{2}$ ), $4.10(\mathrm{q}, J=1.5 \mathrm{~Hz}, 1 \mathrm{H}, \mathrm{Cp}$ ), 3.90-3.35 (very br s, $1 \mathrm{H}, \mathrm{NH}$ of $\left.\mathrm{HNEt}_{3}\right), 3.01\left(\mathrm{q}, J=7.3 \mathrm{~Hz}, 6 \mathrm{H}, \mathrm{CH}_{3} \mathrm{CH}_{2} \mathrm{~N}\right), 1.99-1.61(\mathrm{~m}, 12 \mathrm{H}$, Cy), $1.45^{-0.98}(\mathrm{~m}, 12 \mathrm{H}, \mathrm{Cy}), 1.29(\mathrm{~s}, 9 \mathrm{H}, t \mathrm{Bu}), 1.26(\mathrm{~s}, 9 \mathrm{H}, t \mathrm{Bu})$, $1.25\left(\mathrm{t}, J=7.3 \mathrm{~Hz}, 9 \mathrm{H}, \mathrm{CH}_{3} \mathrm{CH}_{2} \mathrm{~N}\right), 0.85-0.12\left(\mathrm{~m}, 3 \mathrm{H}, \mathrm{BH}_{3}\right) \mathrm{ppm}$. ${ }^{13} \mathrm{C}\left\{{ }^{1} \mathrm{H}\right\}$ NMR (101 MHz, $\left.\mathrm{CD}_{2} \mathrm{Cl}_{2}\right): \delta=169.88(\mathrm{CONH}), 106.84(\mathrm{~d}, J$ $=6 \mathrm{~Hz}, \mathrm{C}^{\mathrm{ipso}}-t \mathrm{Bu}$ of $\left.\mathrm{Cp}\right), 106.61\left(\mathrm{C}^{\mathrm{ipso}}-t \mathrm{Bu}\right.$ of $\left.\mathrm{Cp}\right), 76.05\left(\mathrm{C}^{\mathrm{ipso}}{ }_{-}\right.$ CONH of Cp), 72.44 (d, $J=5 \mathrm{~Hz}, C H$ of $C \mathrm{p}$ ), 70.96 (d, $J=7 \mathrm{~Hz}$, $\mathrm{CH}$ of $\mathrm{Cp}), 70.50\left(\mathrm{~d},{ }^{1} J_{\mathrm{PC}}=55 \mathrm{~Hz}, \mathrm{C}^{\text {ipso }}-\mathrm{P}\right.$ of $\left.\mathrm{Cp}\right), 69.93$ (CH of $\left.\mathrm{Cp}\right)$, 69.48 (CH of $\mathrm{Cp}$ ), 69.06 (CH of $\mathrm{Cp}), 66.81(\mathrm{CH}$ of $\mathrm{Cp}), 56.17$ $\left(\mathrm{CH}_{2} \mathrm{SO}_{3}\right), 46.51\left(\mathrm{CH}_{3} \mathrm{CH}_{2} \mathrm{~N}\right), 33.51(\mathrm{~d}, J=10 \mathrm{~Hz}, \mathrm{Cy}), 33.18(\mathrm{~d}, J=$ $10 \mathrm{~Hz}, \mathrm{Cy}), 32.20(\mathrm{CH}$ of $t \mathrm{Bu}), 31.75$ ( $\mathrm{CH}$ of $t \mathrm{Bu}), 31.17$ ( $\mathrm{C}^{\text {ipso }}$ of $t \mathrm{Bu}$ ), 31.03 ( $\mathrm{C}^{\mathrm{ipso}}$ of $\left.t \mathrm{Bu}\right), 28.19$ (Cy), 28.14 (Cy), $27.95(\mathrm{Cy}), 27.84$ (Cy), 27.40 (d, $J=11 \mathrm{~Hz}, \mathrm{Cy}), 27.39$ (Cy), 27.27 (Cy), 27.21 (d, $J \approx 12$ $\mathrm{Hz}, \mathrm{Cy}), 26.52(\mathrm{Cy}), 26.47(\mathrm{Cy}), 9.27\left(\mathrm{CH}_{3} \mathrm{CH}_{2} \mathrm{~N}\right)$ ppm. ${ }^{31} \mathrm{P}\left\{{ }^{1} \mathrm{H}\right\}$ NMR (162 MHz, $\mathrm{CD}_{2} \mathrm{Cl}_{2}$ ): $\delta=25.2$ (br s) ppm. FTIR (Nujol): $v_{\max }=$ $3412 \mathrm{~m}, 2377 \mathrm{~m}$ (borane), $2274 \mathrm{w}, 1648 \mathrm{~m}$ (CO), $1540 \mathrm{~m}, 1263 \mathrm{~m}$, $1202 \mathrm{~m}, 1178 \mathrm{~m}, 1062 \mathrm{~m}, 1038 \mathrm{~m}, 972 \mathrm{w}, 931 \mathrm{w}, 920 \mathrm{w}, 903 \mathrm{w}, 890$ w, 853 w, 822 w, 755 w, 722 w, 670 w, 616 w, 596 w, 519 w, 473 w, $435 \mathrm{w} \mathrm{cm}^{-1}$. Anal. Calc. for $\mathrm{C}_{38} \mathrm{H}_{68} \mathrm{~N}_{2} \mathrm{BFePO}_{4} \mathrm{~S}$ (746.7): $\mathrm{C} 61.13, \mathrm{H}$ 9.18, N 3.75\%. Found: C 61.07, H 9.35, N 3.35\%. ESI-MS: $m / z 644$ $\left(\left[\mathrm{M}-\mathrm{HNEt}_{3}\right]^{+}\right)$.

Deprotection of $2^{\mathrm{Cy}} \cdot \mathrm{BH}_{3}$. Compound $2^{\mathrm{Cy}} \cdot \mathrm{BH}_{3}(691 \mathrm{mg}, 1.0$ $\mathrm{mmol})$ was dissolved in morpholine $(7 \mathrm{~mL})$. The mixture was degassed by three freeze-pump-thaw cycles and then heated at $65^{\circ} \mathrm{C}$ for $16 \mathrm{~h}$ before evaporating under reduced pressure. The oily residue was transferred onto the top of a silica gel column packed in degassed $\mathrm{CH}_{2} \mathrm{Cl}_{2} / \mathrm{MeOH} / \mathrm{Et}_{3} \mathrm{~N}$ (100:5:5). A single orange band was eluted with degassed $\mathrm{CH}_{2} \mathrm{Cl}_{2} / \mathrm{MeOH}$ (20:1) and evaporated. The gummy residue was crystallized from hot ethyl acetate (ca. $5 \mathrm{~mL}$ ) to produce $2^{\mathrm{Cy}}$ as an orange-red microcrystalline solid ( $487 \mathrm{mg}, 66 \%)$

Synthesis of $6^{\mathrm{Ph}}$. Solid $\left[\mathrm{Pd}(\mu-\mathrm{Cl})\left(\eta^{3}-\mathrm{C}_{3} \mathrm{H}_{5}\right)\right]_{2} \quad(18.3 \mathrm{mg}$, 0.05 $\mathrm{mmol})$ and $\mathbf{1}^{\mathrm{Ph}}$ (60.9 $\mathrm{mg}$, o.10 $\left.\mathrm{mmol}\right)$ were dissolved in dry dichloromethane $(5 \mathrm{~mL})$. After stirring for $30 \mathrm{~min}$, a solution of silver(I) tetrafluoroborate $(19.4 \mathrm{mg}, 0.10 \mathrm{mmol})$ in $\mathrm{MeOH}(1 \mathrm{~mL})$ was added, causing immediate separation of an off-white precipitate $(\mathrm{AgCl})$ and a colour change from orange to orangebrown. The resulting mixture was stirred for $1 \mathrm{~h}$ and filtered through a plug of Dicalite filter aid. The filtrate was evaporated and re-dissolved in dichloromethane $(5 \mathrm{~mL})$. The solution was washed three times with distilled water $(5 \mathrm{~mL}$ each) to remove $\mathrm{Et}_{3} \mathrm{NH}\left[\mathrm{BF}_{4}\right]$, dried over magnesium sulfate, and evaporated. The residue was taken up with dichloromethane/methanol (20/1) and filtered through a pad of silica gel to provide pure $6^{\mathbf{P h}}$ as an orange solid after evaporation. Crystallization by liquid-phase diffusion of pentane into a solution of the complex in $\mathrm{CH}_{2} \mathrm{Cl}_{2} / \mathrm{MeOH}$ (20:1) gave orange crystals. Yield: $54 \mathrm{mg}(82 \%)$. Crystals used for X-ray diffraction analysis were grown from chloroform/pentane.

${ }^{1} \mathrm{H}$ NMR $\left(400 \mathrm{MHz}, \mathrm{CDCl}_{3}, 25^{\circ} \mathrm{C}\right): \delta=7.49-7.36(\mathrm{~m}, 10 \mathrm{H}, \mathrm{Ph})$ $7.32(\mathrm{t}, J=6.7 \mathrm{~Hz}, 1 \mathrm{H}, \mathrm{NH}), 5.78\left(\mathrm{qi}, J=9.9 \mathrm{~Hz}, 1 \mathrm{H}, \mathrm{C}_{3} \mathrm{H}_{5}\right), 5.6 \mathrm{o}-$ 5.00 (very br s, $1 \mathrm{H}, \mathrm{C}_{3} \mathrm{H}_{5}$ ), 5.00-4.30 (br s, $2 \mathrm{H}$ of $\mathrm{Cp}$ and $1 \mathrm{H}$ of $\left.\mathrm{C}_{3} \mathrm{H}_{5}\right), 4.84(\mathrm{t}, J=1.9 \mathrm{~Hz}, 2 \mathrm{H}, \mathrm{Cp}), 4.49$ (br s, $\left.2 \mathrm{H}, \mathrm{Cp}\right), 4.21(\mathrm{t}, J=$
$1.9 \mathrm{~Hz}, 2 \mathrm{H}, \mathrm{Cp}$ ), 3.6o-2.6o (very br s, $2 \mathrm{H}, \mathrm{C}_{3} \mathrm{H}_{5}$ or $\mathrm{CH}_{2}$ ) ppm. ${ }^{1} \mathrm{H}$ $\operatorname{NMR}\left(400 \mathrm{MHz}, \mathrm{CDCl}_{3}, 50^{\circ} \mathrm{C}\right): \delta=7.51-7.36(\mathrm{~m}, 10 \mathrm{H}, \mathrm{Ph}), 7.06(\mathrm{t}$, $J=6.7 \mathrm{~Hz}, 1 \mathrm{H}, \mathrm{NH}), 5.76\left(\mathrm{qi}, J=9.9 \mathrm{~Hz}, 1 \mathrm{H}, \mathrm{C}_{3} \mathrm{H}_{5}\right), 4.75(\mathrm{t}, J=1.9$ $\mathrm{Hz}, 2 \mathrm{H}, \mathrm{Cp}$ ), 4.68 (br s, $2 \mathrm{H}, \mathrm{C}_{3} \mathrm{H}_{5}$ or $\mathrm{Cp}$ ), 4.66 (br s, $2 \mathrm{H}, \mathrm{C}_{3} \mathrm{H}_{5}$ or Cp), 4.51 (br t, $J=1.8 \mathrm{~Hz}, 2 \mathrm{H}, \mathrm{Cp}$ ), 4.35-3.09 (br s, $2 \mathrm{H}, \mathrm{C}_{3} \mathrm{H}_{5}$ or $\left.\mathrm{CH}_{2}\right), 4.19(\mathrm{t}, J=1.9 \mathrm{~Hz}, 2 \mathrm{H}, \mathrm{Cp}) \mathrm{ppm}$. At both temperatures, signals due to 2 hydrogen atoms of $\mathrm{C}_{3} \mathrm{H}_{5}$ and/or $\mathrm{CH}_{2} \mathrm{SO}_{3}$ were not observed due to extensive broadening. ${ }^{31} \mathrm{P}\left\{{ }^{1} \mathrm{H}\right\}$ NMR $(161$ $\mathrm{MHz}, \mathrm{CDCl}_{3}, 25^{\circ} \mathrm{C}$ ): $\delta=14.8$ (s) ppm. FTIR of $\mathbf{6}^{\mathrm{Ph}}-\mathrm{C}$ (DRIFTS, $\mathrm{KBr}): v_{\max }=3312 \mathrm{w}, 3233 \mathrm{w}, 3088 \mathrm{w}, 1641 \mathrm{~m}, 1596 \mathrm{~m}, 1541 \mathrm{~m}, 1480$ w, $1436 \mathrm{~m}, 1402 \mathrm{w}, 1387 \mathrm{w}, 1314 \mathrm{w}, 1257 \mathrm{~m}, 1228 \mathrm{~m}, 1220 \mathrm{~m}, 1185 \mathrm{~m}$, 1154 s, 1099 w, 1074 w, 1044 m, 1035 w, 963 w, 912 w, 897 w, 844 w, $828 \mathrm{w}, 751 \mathrm{~m}, 694 \mathrm{~m}, 611 \mathrm{~m}, 541 \mathrm{w}, 532 \mathrm{~m}, 516 \mathrm{~s}, 490 \mathrm{~m}, 469 \mathrm{~m}$, $450 \mathrm{~m} \mathrm{~cm}^{-1}$. FTIR of $6^{\mathrm{Ph}}-\mathrm{S}$ (DRIFTS, KBr): $v_{\max }=3319 \mathrm{~s}, 3116 \mathrm{w}$, $300 \mathrm{w}, 3085 \mathrm{w}, 3057 \mathrm{~m}, 2955 \mathrm{~m}, 2871 \mathrm{w}, 1641 \mathrm{~s}, 1586 \mathrm{w}, 1538 \mathrm{~m}$, $1532 \mathrm{~m}, 1481 \mathrm{w}, 1456 \mathrm{w}, 1435 \mathrm{~m}, 1402 \mathrm{w}, 1388 \mathrm{w}, 1379$ w, $1363 \mathrm{w}, 1312$ m, 1258 s, 1214 m, 1155 vs, 1099 m, 1074 w, 1058 w, 1027 m, 1019 m, 911 w, 892 w, 869 w, 857 w, 823 w, 817 w, 747 m, 705 m, 694 m, $668 \mathrm{w}, 626 \mathrm{w}, 613 \mathrm{~m}, 590 \mathrm{w}, 583 \mathrm{w}, 552 \mathrm{w}, 541 \mathrm{w}, 528 \mathrm{~m}, 514 \mathrm{~m}$, $494 \mathrm{~m}, 480 \mathrm{w}, 469 \mathrm{~m}, 451 \mathrm{w}, 439 \mathrm{~m}, 430 \mathrm{w} \mathrm{cm}^{-1}$. Anal. Calc. for $\mathrm{C}_{27} \mathrm{H}_{26} \mathrm{NFeO}_{4} \mathrm{PPdS} \cdot 0.3 \mathrm{CH}_{2} \mathrm{Cl}_{2}$ (679.28): $\mathrm{C} 48.27, \mathrm{H}$ 3.95, N 2.06\%. Found: $\mathrm{C} 48.34, \mathrm{H} 4.03, \mathrm{~N} 2.12 \%$. The amount of clathrated solvent was verified by NMR analysis $\left(\delta_{\mathrm{H}} 5.30\right)$. HR ESI-MS calc. for $\mathrm{C}_{27} \mathrm{H}_{26} \mathrm{NNaPO}_{4} \mathrm{FeSPd}\left([\mathrm{M}+\mathrm{Na}]^{+}\right): 675.9597$, found: 675.9613 .

Synthesis of $6^{\mathrm{Cy}}$. Compound $6^{\mathrm{Cy}}$ was prepared similarly, using $\left[\operatorname{Pd}(\mu-\mathrm{Cl})\left(\eta^{3}-\mathrm{C}_{3} \mathrm{H}_{5}\right)\right]_{2}(17.5 \mathrm{mg}, 0.048 \mathrm{mmol})$ and $1^{\mathrm{Cy}}(59.5 \mathrm{mg}$, $0.096 \mathrm{mmol})$ in dry dichloromethane $(5 \mathrm{~mL})$ and $\mathrm{Ag}\left[\mathrm{BF}_{4}\right](18.7$ $\mathrm{mg}, 0.096 \mathrm{mmol})$ in $\mathrm{MeOH}(1 \mathrm{~mL})$. Purification and crystallization as described above produced $6^{\mathrm{Cy}}$ as an orange crystalline solid. Yield: $51 \mathrm{mg}$ (80\%).

${ }^{1} \mathrm{H}$ NMR $\left(400 \mathrm{MHz}, \mathrm{CDCl}_{3}, 25^{\circ} \mathrm{C}\right): \delta=7.87(\mathrm{t}, J=6.7 \mathrm{~Hz}, 1 \mathrm{H}$, $\mathrm{NH}$ ), 5.71 (qi, $J=9.9 \mathrm{~Hz}, 1 \mathrm{H}, \mathrm{C}_{3} \mathrm{H}_{5}$ ), 4.96 (br m, $\left.2 \mathrm{H}, \mathrm{Cp}\right), 4.74(\mathrm{br}$ $\mathrm{m}, 2 \mathrm{H}, \mathrm{Cp}), 4.62\left(\mathrm{br} \mathrm{d}, J=6.6 \mathrm{~Hz}, 2 \mathrm{H}, \mathrm{CH}_{2}\right), 4.53(\mathrm{br} \mathrm{m}, 2 \mathrm{H}$, Cp), 4.41 (br m, $2 \mathrm{H}, \mathrm{Cp}$ ). 4.00-3.20 (very br s, $2 \mathrm{H}, \mathrm{C}_{3} \mathrm{H}_{5}$ ), 3.202.50 (very br s, $2 \mathrm{H}, \mathrm{C}_{3} \mathrm{H}_{5}$ ), 2.09-1.65 (m, $\left.11 \mathrm{H}, \mathrm{Cy}\right)$, 1.41-1.09 (m, 11 $\mathrm{H}, \mathrm{Cy}) \mathrm{ppm} .{ }^{31} \mathrm{P}\left\{{ }^{1} \mathrm{H}\right\}$ NMR $\left(161 \mathrm{MHz}, \mathrm{CDCl}_{3}, 25^{\circ} \mathrm{C}\right): \delta=27.3$ (s) $\mathrm{ppm}$. The data agree with those found in the literature..$^{\mathrm{c}}$

Synthesis of $7^{\mathrm{Ph}}$. Solids $\left[\mathrm{Pd}(\mu-\mathrm{Cl})\left(\eta^{3}-\mathrm{C}_{3} \mathrm{H}_{5}\right)\right]_{2}$ (56.o mg, o.15 $\mathrm{mmol})$ and $2^{\mathbf{P h}}(216.2 \mathrm{mg}, 0.30 \mathrm{mmol})$ were dissolved in dry dichloromethane (10 mL). After stirring for $30 \mathrm{~min}$, a solution of $\mathrm{Ag}\left[\mathrm{BF}_{4}\right](59.6 \mathrm{mg}, 0.30 \mathrm{mmol})$ in $\mathrm{MeOH}(1.5 \mathrm{~mL})$ was added, resulting in the separation of an off-white solid $(\mathrm{AgCl})$ and a colour change from orange to orange-brown. The resulting mixture was stirred for $1 \mathrm{~h}$ and filtered through a cotton plug. The filtrate was evaporated and re-dissolved in dichloromethane (10 $\mathrm{mL}$ ). The solution was washed three times with $10 \mathrm{~mL}$ of distilled water to remove $\mathrm{Et}_{3} \mathrm{NH}\left[\mathrm{BF}_{4}\right]$, dried over magnesium sulfate, and evaporated. The residue was dissolved in dichloromethane/methanol (20:1) and filtered through a pad of silica gel. The filtrate was evaporated, and the residue was crystallized by dissolving in dichloromethane/methanol (20:1, $5 \mathrm{~mL})$ and layering with pentane (ca. $15 \mathrm{~mL}$ ). The crystals, which separated for several days, were filtered off and dried under vacuum to give $7^{\mathbf{P h}}$ as an orange crystalline solid. Yield: $196 \mathrm{mg}(85 \%)$.

${ }^{1} \mathrm{H}$ NMR (40o $\left.\mathrm{MHz}, \mathrm{CDCl}_{3}, 25^{\circ} \mathrm{C}\right): \delta=7.84-7.75(\mathrm{~m}, 2 \mathrm{H}, \mathrm{Ph})$, 7.53-7.47 (m, $3 \mathrm{H}, \mathrm{Ph}), 7 \cdot 37-7.24(\mathrm{~m}, 3 \mathrm{H}, \mathrm{Ph})$, 7.06-6.98 (m, $2 \mathrm{H}$, $\mathrm{Ph}), 6.62(\mathrm{dd}, J=10.8,2.2 \mathrm{~Hz}, 1 \mathrm{H}, \mathrm{NH}), 5.79\left(\mathrm{br} \mathrm{s}, 1 \mathrm{H}, \mathrm{C}_{3} \mathrm{H}_{5}\right), 5.63$ (br s, $1 \mathrm{H}, \mathrm{Cp}$ ), 5.30 (dd, $\left.J=13.6,11.0 \mathrm{~Hz}, 1 \mathrm{H}, \mathrm{C}_{3} \mathrm{H}_{5}\right), 4.77$ (br s, $1 \mathrm{H}$, Cp), $4.71(\mathrm{dd}, J=2.7,1.4 \mathrm{~Hz}, 1 \mathrm{H}, \mathrm{Cp}), 4.27(\mathrm{dd}, J=2.6,1.8 \mathrm{~Hz}, 1 \mathrm{H}$, 
Lorsqu'un écrit scientifique issu d'une activité de recherche financée au moins pour moitié par des dotations de l'État, des collectivités territoriales ou des établissements publics, par des subventions d'agences de financement nationales ou par des fonds de l'Union européenne est publié dans un périodique paraissant au moins une fois par an, son auteur dispose, même après avoir accordé des droits exclusifs à un éditeur, du droit de mettre à disposition gratuitement dans un format ouvert, par voie numérique, sous réserve de l'accord des éventuels coauteurs, la version finale de son manuscrit acceptée pour publication, dès lors que l'éditeur met lui-même celle-ci gratuitement à disposition par voie numérique ou, à défaut, à l'expiration d'un délai courant à compter de la date de la première publication. Ce délai est au maximum de six mois pour une publication dans le domaine des sciences, de la technique et de la médecine et de douze mois dans celui des sciences humaines et sociales.

Cp), 4.17 (dd, $J=2.5,1.6 \mathrm{~Hz}, 1 \mathrm{H}, \mathrm{Cp}$ ), 4.10-2.50 (very br s, $1 \mathrm{H}$, $\mathrm{C}_{3} \mathrm{H}_{5}$ or $\left.\mathrm{CH}_{2} \mathrm{SO}_{3}\right), 3.97\left(\mathrm{dd}, J=13.7,2.6 \mathrm{~Hz}, 1 \mathrm{H}, \mathrm{C}_{3} \mathrm{H}_{5}\right), 3.72(\mathrm{td}, J=$ 2.1, 1.4 Hz, $1 \mathrm{H}, \mathrm{Cp}), 1.37$ (s, $9 \mathrm{H}, t \mathrm{Bu}), 0.82(\mathrm{~s}, 9 \mathrm{H}, t \mathrm{Bu}) \mathrm{ppm} .{ }^{1} \mathrm{H}$ NMR (40o $\left.\mathrm{MHz}, \mathrm{CDCl}_{3}, 50^{\circ} \mathrm{C}\right): \delta=7.84-7.77(\mathrm{~m}, 2 \mathrm{H}, \mathrm{Ph}), 7.51^{-}$ $7.47(\mathrm{~m}, 3 \mathrm{H}, \mathrm{Ph}), 7.36-7.24(\mathrm{~m}, 3 \mathrm{H}, \mathrm{Ph}), 7.06-6.99(\mathrm{~m}, 2 \mathrm{H}, \mathrm{Ph})$, $6.54(\mathrm{dd}, J=11.1,2.1 \mathrm{~Hz}, 1 \mathrm{H}, \mathrm{NH}), 5.78\left(\mathrm{qi}, J=9.8 \mathrm{~Hz}, 1 \mathrm{H}, \mathrm{C}_{3} \mathrm{H}_{5}\right)$ $5.64(\mathrm{dt}, J=3.0,1.5 \mathrm{~Hz}, 1 \mathrm{H}, \mathrm{Cp}), 5.27(\mathrm{dd}, J=13.6,10.9 \mathrm{~Hz}, 1 \mathrm{H}$, $\mathrm{C}_{3} \mathrm{H}_{5}$ ), 4.75 (br s, $1 \mathrm{H}, \mathrm{Cp}$ ), $4.7 \mathrm{o}$ (dd, $J=2.8,1.4 \mathrm{~Hz}, 1 \mathrm{H}, \mathrm{Cp}$ ), 4.25 (dd, $J=2.7,1.7 \mathrm{~Hz}, 1 \mathrm{H}, \mathrm{Cp}$ ), 4.16 (dd, $J=2.5,1.6 \mathrm{~Hz}, 1 \mathrm{H}, \mathrm{Cp}), 3.95$ (dd, $\left.J=13.6,2.6 \mathrm{~Hz}, 1 \mathrm{H}, \mathrm{C}_{3} \mathrm{H}_{5}\right), 3.73(\mathrm{td}, J=2.2,1.4 \mathrm{~Hz}, 1 \mathrm{H}, \mathrm{Cp}$ ), $4.40-3.22$ (very br s, $1 \mathrm{H}, \mathrm{C}_{3} \mathrm{H}_{5}$ or $\left.\mathrm{CH}_{2} \mathrm{SO}_{3}\right), 1.37(\mathrm{~s}, 9 \mathrm{H}, t \mathrm{Bu})$, $0.83(\mathrm{~s}, 9 \mathrm{H}, t \mathrm{Bu}) \mathrm{ppm}$. At both temperatures, the signals of three hydrogen atoms from $\mathrm{C}_{3} \mathrm{H}_{5}$ and $\mathrm{CH}_{2} \mathrm{SO}_{3}$ could not be unequivocally identified due to extensive broadening. ${ }^{31} \mathrm{P}\left\{{ }^{1} \mathrm{H}\right\}$ NMR (161 $\mathrm{MHz}, \mathrm{CDCl}_{3}, 25^{\circ} \mathrm{C}$ ): $\delta=14.2(\mathrm{~s})$ ppm. FTIR (DRIFTS, $\mathrm{KBr}$ ): $v_{\max }=$ 3504 w, 3441 w, 3339 w, 3097 w, 3058 w, 2963 m, 2905 w, 2867 w, $1643 \mathrm{~m}, 1526 \mathrm{~m}, 1482 \mathrm{~m}, 1459 \mathrm{w}, 1435 \mathrm{~m}, 1400 \mathrm{w}, 1365 \mathrm{~m}, 1314 \mathrm{w}$, $1270 \mathrm{~m}, 1258 \mathrm{~s}, 1214 \mathrm{w}, 1179 \mathrm{~m}, 1150 \mathrm{vs}, 1097 \mathrm{w}, 108 \mathrm{o}$ w, $1013 \mathrm{~m}, 973$ w, $920 \mathrm{w}, 856 \mathrm{w}, 824 \mathrm{w}, 750 \mathrm{~m}, 728 \mathrm{w}, 704 \mathrm{w}, 697 \mathrm{~s}, 616 \mathrm{w}, 588 \mathrm{w}$, $560 \mathrm{w}, 539 \mathrm{~m}, 524 \mathrm{~m}, 509 \mathrm{~s}, 493 \mathrm{~m}, 481 \mathrm{~m}, 440 \mathrm{w} \mathrm{cm}^{-1}$. Anal. Calc. for $\mathrm{C}_{35} \mathrm{H}_{42} \mathrm{NFeO}_{4} \mathrm{PPdS} \cdot 0.8 \mathrm{CH}_{2} \mathrm{Cl}_{2}(833.96)$ : $\mathrm{C}$ 51.56, $\mathrm{H}$ 5.27, $\mathrm{N}$ 1.68\%. Found: $\mathrm{C} 51.42, \mathrm{H} 5.43, \mathrm{~N} \mathrm{1.72} \%$. The amount of residual solvent was confirmed by NMR analysis $\left(\delta_{\mathrm{H}} 5.30\right)$. HR ESI-MS calc. for $\mathrm{C}_{35} \mathrm{H}_{42} \mathrm{FeNNaO}_{4} \mathrm{PPdS}\left([\mathrm{M}+\mathrm{Na}]^{+}\right)$: 788.08486, found: 788.08674 .

Synthesis of $7^{\mathrm{Cy}}$. Compound $7^{\mathrm{Cy}}$ was prepared in an analogous manner starting from $2^{\mathrm{Cy}}(219.9 \mathrm{mg}, 0.30 \mathrm{mmol})$. Crystallization by dissolving the crude product in dichloromethane/methanol $(20 / 1,3 \mathrm{~mL})$ and layering with pentane (10 $\mathrm{mL}$ ) provided $7^{\mathrm{Cy}}$ as an orange-red crystalline solid. Yield: $194 \mathrm{mg}$ $(83 \%)$.

${ }^{1} \mathrm{H}$ NMR $\left(400 \mathrm{MHz}, \mathrm{CDCl}_{3}, 25^{\circ} \mathrm{C}\right): \delta=6.99(\mathrm{br} \mathrm{s}, 1 \mathrm{H}, \mathrm{NH}), 5.70$ (qi, $J=9.5 \mathrm{~Hz}, 1 \mathrm{H}, \mathrm{C}_{3} \mathrm{H}_{5}$ ), $5.26(\mathrm{dt}, J=2.8,1.5 \mathrm{~Hz}, 1 \mathrm{H}, \mathrm{Cp}$ ), 5.13 (dd, $J=13.6,10.5 \mathrm{~Hz}, 1 \mathrm{H}, \mathrm{C}_{3} \mathrm{H}_{5}$ ), 4.80 (br s, $1 \mathrm{H}, \mathrm{Cp}$ ), 4.73 (br s, 1 $\mathrm{H}, \mathrm{Cp}$ ), 4.32 (dd, J= 2.7, $1.8 \mathrm{~Hz}, 1 \mathrm{H}, \mathrm{Cp}$ ), 4.24 (br s, $1 \mathrm{H}, \mathrm{Cp}$ ), 4.14 (dd, $J=2.4,1.6 \mathrm{~Hz}, 1 \mathrm{H}, \mathrm{Cp}$ ), 3.97 (dd, $J=13.6,2.0 \mathrm{~Hz}, 1 \mathrm{H}, \mathrm{C}_{3} \mathrm{H}_{5}$ ), 3.49 (br s, $2 \mathrm{H}, \mathrm{CH}_{2} \mathrm{SO}_{3}$ ), 2.68-2.58 (m, $\left.1 \mathrm{H}, \mathrm{Cy}\right), 1.33(\mathrm{~s}, 9 \mathrm{H}, t \mathrm{Bu})$, $1.23(\mathrm{~s}, 9 \mathrm{H}, t \mathrm{Bu}), 2.20-0.64(\mathrm{~m}, 21 \mathrm{H}, \mathrm{Cy}) \mathrm{ppm}$. Two signals with integral intensities corresponding to two hydrogen atoms at $\mathrm{C}_{3} \mathrm{H}_{5}$ were not observed due to broadening. ${ }^{1} \mathrm{H} \mathrm{NMR}(400 \mathrm{MHz}$, $\left.\mathrm{CDCl}_{3}, 50^{\circ} \mathrm{C}\right): \delta=6.74(\mathrm{br} \mathrm{d}, J=10.7 \mathrm{~Hz}, 1 \mathrm{H}, \mathrm{NH}), 5.67$ (qi, $J=9.9$ $\left.\mathrm{Hz}, 1 \mathrm{H}, \mathrm{C}_{3} \mathrm{H}_{5}\right), 5.28(\mathrm{dt}, J=2.8,1.5 \mathrm{~Hz}, 1 \mathrm{H}, \mathrm{Cp}), 5.12(\mathrm{dd}, J=13.6$, $10.6 \mathrm{~Hz}, 1 \mathrm{H}, \mathrm{C}_{3} \mathrm{H}_{5}$ ), $4.8 \mathrm{o}-4.04$ (very br s, $1 \mathrm{H}, \mathrm{C}_{3} \mathrm{H}_{5}$ ), 4.75 (dd, $J=$ 2.7, 1.4 Hz, $1 \mathrm{H}, \mathrm{Cp}$ ), 4.72 (t, $J=1.6 \mathrm{~Hz}, 1 \mathrm{H}, \mathrm{Cp}), 4.30$ (dd, $J=2.7$, $1.8 \mathrm{~Hz}, 1 \mathrm{H}, \mathrm{Cp}$ ), $4.23(\mathrm{dt}, J=2.5,1.2 \mathrm{~Hz}, 1 \mathrm{H}, \mathrm{Cp}), 4.14(\mathrm{dd}, J=2.5$, $1.6 \mathrm{~Hz}, 1 \mathrm{H}, \mathrm{Cp}$ ), $4.04-3.31$ (very br s, $1 \mathrm{H}, \mathrm{C}_{3} \mathrm{H}_{5}$ ) 3.94 (dd, $J=13.5$, $\left.2.9 \mathrm{~Hz}, 1 \mathrm{H}, \mathrm{C}_{3} \mathrm{H}_{5}\right), 3.48$ (br s, $\left.2 \mathrm{H}, \mathrm{CH}_{2} \mathrm{SO}_{3}\right), 2.66-2.57(\mathrm{~m}, 1 \mathrm{H}$ $\mathrm{Cy})$, 2.24-0.70 (m, $21 \mathrm{H}, \mathrm{Cy}), 1.34(\mathrm{~s}, 9 \mathrm{H}, t \mathrm{Bu}), 1.24(\mathrm{~s}, 9 \mathrm{H}, t \mathrm{Bu})$ ppm. ${ }^{31} \mathrm{P}\left\{{ }^{1} \mathrm{H}\right\}$ NMR $\left(161 \mathrm{MHz}, \mathrm{CDCl}_{3}, 25^{\circ} \mathrm{C}\right): \delta=27.2$ (br s) ppm. FTIR (DRIFTS, KBr): $v_{\max }=3599 \mathrm{w}, 3450 \mathrm{w}, 3240 \mathrm{~m}, 3102 \mathrm{w}, 3062$ w, 2958 m, 2930 s, 2853 m, 1644 w, 1574 s, 1484 w, 1456 m, 1448 m, 1407 w, 1389 w, 1365 m, 1332 m, 1290 w, 1271 m, 1223 m, 1197 m, 1178 s, 1155 m, 1114 w, 1092 w, 1038 m, 1007 w, 966 w, 918 w, 907 w, $890 \mathrm{w}, 855 \mathrm{w}, 831 \mathrm{w}, 813 \mathrm{w}, 771 \mathrm{w}, 746 \mathrm{~m}, 679 \mathrm{w}, 616 \mathrm{~m}, 592 \mathrm{w}, 539$ $\mathrm{w}, 525 \mathrm{~m}, 508 \mathrm{~m}, 493 \mathrm{~m}, 478 \mathrm{w} \mathrm{cm}$. . Anal. Calc. for $\mathrm{C}_{35} \mathrm{H}_{54} \mathrm{NFeO}_{4} \mathrm{PPdS} \cdot 0 .{ }_{3} \mathrm{CH}_{2} \mathrm{Cl}_{2}$ (803.6): $\mathrm{C}$ 52.76, $\mathrm{H}$ 6.85, $\mathrm{N} 1.74 \%$. Found: $\mathrm{C} 52.85, \mathrm{H} 6.84, \mathrm{~N} 1.56 \%$. The amount of residual solvent was confirmed by NMR analysis $\left(\delta_{\mathrm{H}} 5 \cdot 30\right)$. HR ESI-MS calc. for $\mathrm{C}_{27} \mathrm{H}_{26} \mathrm{NNaPO}_{4} \mathrm{FeSPd}\left([\mathrm{M}+\mathrm{Na}]^{+}\right)$: 80o.17876, found: 80o.18026.
Catalytic Experiments. In air, the preformed catalyst $7^{\mathrm{R}}$ or $6^{\mathrm{R}}$ (1 mol.\% based on indole) was placed into a Schlenk tube equipped with a stirring bar, followed by indole $(58.6 \mathrm{mg}$, 0.50 mmol) and $\mathrm{KHCO}_{3}$ as the base (150 $\mathrm{mg}, 1.50 \mathrm{mmol} ; 3$ equiv.). Solid iodoarenes (o.6o mmol, 1.2 equiv) were added at this stage before deoxygenating the solid mixture through three vacuum/argon cycles. Liquid iodoarenes were added by syringe after deoxygenation. Next, $2 \mathrm{~mL}$ of degassed water (bubbled for 30 min with argon) were added and the Schlenk tube was transferred into a preheated oil bath $\left(100 \pm 2^{\circ} \mathrm{C}\right)$ and stirred for $24 \mathrm{~h}$. All reactions were clearly biphasic, potentially limiting the mass transfer, which was also the limitation for the conversion. The reaction was terminated by cooling to room temperature and adding dichloromethane $(5 \mathrm{~mL})$. The organic phase was separated, and the water phase was washed two times using $5 \mathrm{~mL}$ of dichloromethane. The combined organic phases were dried over $\mathrm{MgSO}_{4}$ and evaporated after filtration. The resulting crude products were dissolved in DMSO- $\mathrm{d}_{6}$ and analysed by NMR spectroscopy.

X-ray Crystallography. Full-sphere diffraction data $( \pm h \pm k \pm l$, $\theta_{\max }=27.5^{\circ}$ ) were collected with a Bruker D8 VENTURE Kappa Duo diffractometer equipped with a Cryostream Cooler (Oxford Cryosystems) using CuK $\alpha\left(\lambda=1.54178 \AA\right.$; only for $\left.2^{\mathrm{Cy}} \cdot \mathrm{BH}_{3}\right)$ or Mo $\mathrm{K} \alpha(\lambda=0.71073 \AA$; all other compounds $)$ radiation. The structures were obtained using direct methods (SHELXT, recent version $^{23}$ ) and subsequently refined by full-matrix least-squares based on $F^{2}$ (SHELXL-2017 ${ }^{24}$ ). Nonhydrogen atoms were refined with anisotropic displacement parameters. Amide NH (except for $\mathbf{6}^{\mathbf{P h}}-\mathbf{C} \cdot \mathrm{CH}_{2} \mathrm{Cl}_{2} \cdot \mathrm{MeOH}$ ) and $\mathrm{BH}_{3}$ hydrogens were identified on the difference electron density maps and refined as riding atoms with $U_{\text {iso }}(\mathrm{H})$ set to $1.2 U_{\text {eq }}$ of their bonding atom. Hydrogen atoms in the $\mathrm{CH}_{\mathrm{n}}$ groups were placed in their theoretical positions and refined similarly. Particular details are as follows.

Compound $2^{\mathrm{Cy}} \cdot \mathrm{BH}_{3}$ crystallised as a three-component, nonmerohedral twin. The refined contributions of the three domains were approximately 0.661:0.214:0.125. In the structure of $\mathbf{2}^{\mathbf{P h}}$, one ethyl substituent of the $\mathrm{Et}_{3} \mathrm{NH}^{+}$cation had to be refined over two positions due to disorder. Similarly, the allyl moieties in all $\operatorname{Pd}\left(\eta^{3}\right.$-allyl $)$ complexes reported here were disordered and had to be modelled over two positions, rotated approximately $180^{\circ}$ along the Pd-allyl axis. The solvent molecules in the structure of $7^{\mathrm{Cy}} \cdot 0.125 \mathrm{CH}_{2} \mathrm{Cl}_{2} \cdot 0.875 \mathrm{MeOH}$ occupy the same space and were refined so that their occupancies sum up to 1 . Lastly, the solvent molecules in the structures of $\mathbf{6}^{\mathbf{P h}}-\mathbf{C} \cdot \mathrm{CH}_{2} \mathrm{Cl}_{2} \cdot \mathrm{MeOH}$ and $\mathbf{6}^{\mathbf{P h}}$. $\mathrm{S} \cdot 1.5 \mathrm{CHCl}_{3}$ were disordered within structural voids and could not be satisfactorily incorporated in the structure model. Therefore, their contribution to the overall scattering was eliminated using PLATON SQUEEZE. ${ }^{25}$ The removed electron density was in good agreement with the expected value (106 electrons for $\mathbf{6}^{\mathbf{P h}}$ C. $\mathrm{CH}_{2} \mathrm{Cl}_{2} \cdot \mathrm{MeOH}$ with 120 expected, and 696 electrons for $\mathbf{6}^{\mathbf{P h}}$ S.1.5 $\mathrm{CHCl}_{3}$ with 696 electrons expected).

Selected crystallographic data and refinement parameters are available as Supporting Information, Table S1. All geometric data and structural diagrams were obtained using a recent version of the PLATON program. ${ }^{26}$ The numerical values were rounded to one decimal place with respect to their estimated standard deviations (ESDs). Parameters pertaining to atoms in geometrically constrained positions (hydrogens) are given without ESDs. 
Lorsqu'un écrit scientifique issu d'une activité de recherche financée au moins pour moitié par des dotations de l'État, des collectivités territoriales ou des établissements publics, par des subventions d'agences de financement nationales ou par des fonds de l'Union européenne est publié dans un périodique paraissant au moins une fois par an, son auteur dispose, même après avoir accordé des droits exclusifs à un éditeur, du droit de mettre à disposition gratuitement dans un format ouvert, par voie numérique, sous réserve de l'accord des éventuels coauteurs, la version finale de son manuscrit acceptée pour publication, dès lors que l'éditeur met lui-même celle-ci gratuitement à disposition par voie numérique ou, à défaut, à l'expiration d'un délai courant à compter de la date de la première publication. Ce délai est au maximum de six mois pour une publication dans le domaine des sciences, de la technique et de la médecine et de douze mois dans celui des sciences humaines et sociales.

DFT Calculations. Density functional theory calculations were performed using Gaussian 16, revision C.01. ${ }^{27}$ The reported energies correspond to Gibbs free energies obtained after full geometry optimizations, starting from atomic coordinates determined by X-ray diffraction analysis where possible (the more populated orientation of the $\pi$-coordinated allyl group was used), using PBEo density functional ${ }^{28}$ combined with the Stuttgart-Dresden core potential ${ }^{29}$ for $\mathrm{Fe}$ and Pd and Jul-cc-pVDZ ${ }^{30}$ basis set for the remaining atoms. The solvent effects were approximated using the polarised continuum model (PCM). ${ }^{18}$ Cartesian coordinates of the DFT optimized structures are available in the Supporting Information.

\section{ASSOCIATED CONTENT}

\section{Supporting Information}

The Supporting Information is available free of charge at http://pubs.acs.org/doi/10.1021/acs.organomet. XXXX

FTIR spectra of $6^{\mathrm{Ph}}-\mathrm{C}$ and $\mathbf{6}^{\mathrm{Ph}}-\mathrm{S}$, additional structural data and structure diagrams, summary of relevant crystallographic parameters (Table $\mathrm{S}$ ), and copies of the NMR spectra (PDF)

Cartesian coordinates of the DFT optimized structures (XYZ)

\section{Accession Codes}

CCDC 2077801-2077807 contain the supplementary crystallographic data for this paper. These data can be obtained free of charge via www.ccdc.cam.ac.uk/data_request/cif, by emailing data_request@ccdc.cam.ac.uk, or by contacting The Cambridge Crystallographic Data Centre, 12 Union Road, Cambridge CB2 1EZ, UK; fax: +44 1223336033.

\section{AUTHOR INFORMATION}

\section{Corresponding Authors}

Petr Štěpnička - Department of Inorganic Chemistry, Faculty of Science, Charles University, Hlavova 2030, 12840 Prague, Czech Republic; orcid.org/oooo-0oo2-5966-0578; E-mail address: petr.stepnicka@natur.cuni.cz Jean-Cyrille Hierso - Institut de Chimie Moléculaire de l'Université de Bourgogne (ICMUB) UMR CNRS 6302, Université Bourgogne Franche-Comté (UBFC), 9 avenue Alain Savary, 21078 Dijon, France; orcid.org/oooo-0002-2048-647X; E-mail address: jean-cyrille.hierso@u-bourgogne.fr

\section{Authors}

Petr Vosáhlo - Department of Inorganic Chemistry, Faculty of Science, Charles University, Hlavova 2030, 12840 Prague, Czech Republic; orcid.org/oooo-0003-0981-3676
Léa Radal - Institut de Chimie Moléculaire de l'Université de Bourgogne (ICMUB) UMR CNRS 6302, Université Bourgogne Franche-Comté (UBFC), 9 avenue Alain Savary, 21078 Dijon, France

Marine Labonde - Institut de Chimie Moléculaire de l'Université de Bourgogne (ICMUB) UMR CNRS 6302, Université Bourgogne Franche-Comté (UBFC), 9 avenue Alain Savary, 21078 Dijon, France

Ivana Císařová - Department of Inorganic Chemistry, Faculty of Science, Charles University, Hlavova 2030, 12840 Prague, Czech Republic; orcid.org/oooo-0oo2-9612-9831 Julien Roger - Institut de Chimie Moléculaire de l'Université de Bourgogne (ICMUB) UMR CNRS 6302, Université Bourgogne Franche-Comté (UBFC), 9 avenue Alain Savary, 21078 Dijon, France; orcid.org/oooo-0oo2-4964-366X

Nadine Pirio - Institut de Chimie Moléculaire de l'Université de Bourgogne (ICMUB) UMR CNRS 6302, Université Bourgogne Franche-Comté (UBFC), 9 avenue Alain Savary, 21078 Dijon, France; orcid.org/oooo-0oo3-4921-2912

Notes

The authors declare no competing financial interests.

\section{ACKNOWLEDGMENTS}

This article is dedicated to Professor Pierre H. Dixneuf in recognition of his outstanding contributions to organometallic chemistry and catalysis. This work was supported by the Charles University Research Centre Programme (project UNCE/SCI/o14). Computational resources were provided by the project "e-Infrastruktura CZ" (e-INFRA LM2018140) falling within the scheme Projects of Large Research, Development and Innovations Infrastructures. P. V. also thanks the Foundation of Faculty of Science, Charles University for supporting his stay in Dijon. In Dijon, this work was supported by the ANR-PRC 2016 programme (ALCATRAS, ANR16-CEo7-ooo1-o1), the CNRS, Université de Bourgogne, Conseil Régional de Bourgogne through the plan d'actions régional pour l'innovation (PARI), and the fonds européen de développement regional (FEDER). The authors also thank Dr. R. Gyepes from the Department of Inorganic Chemistry, Faculty of Science, Charles University for valuable suggestions regarding DFT computations. Thanks are also due to Dr. H. Cattey from Institut de Chimie Moléculaire de l'Université de Bourgogne, Université Bourgogne FrancheComté for complementary crystallographic measurements.

\section{REFERENCES}




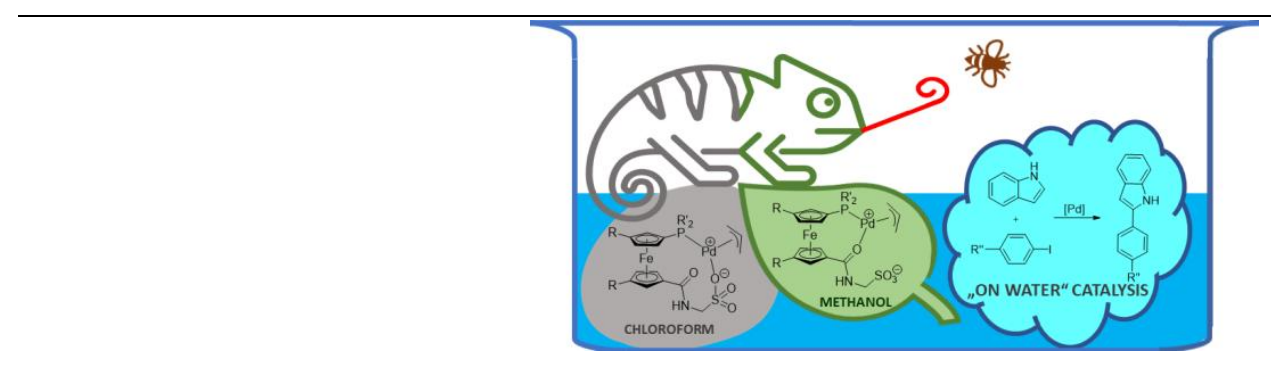

1. Catalysis: From Principles to Applications, Beller, M.; Renken, A.; van Santen, R. A.; Eds., Wiley-VCH: Weinheim, 2012.

2. Phosphorus(III) Ligands in Homogeneous Catalysis: Design and Synthesis, Kamer, P. C. J.; van Leeuwen, P. W. N. M.; Eds., Wiley: Chichester, 2012.

3. (a) Bader, A.; Lindner, E. Coordination chemistry and catalysis with hemilabile oxygen-phosphorus ligands. Coord. Chem. Rev. 1991, 108, 27-110; (b) Slone, C. S.; Weinberger, D. A.; Mirkin, C. A. The Transition Metal Coordination Chemistry of Hemilabile Ligands. Progr. Inorg. Chem. 1999, 48, 233-350.

4. (a) Aqueous-Phase Organometallic Chemistry, Cornils, B.; Herrmann, W. A.; Eds., 2nd ed., Wiley-VCH: Weinheim, 2004; (b) Pinault, N.; Bruce, D. W. Homogeneous catalysts based on water-soluble phosphines. Coord. Chem. Rev. 2003, 241, 1-25; (c) Shaughnessy, K. H. Hydrophilic Ligands and Their Application in Aqueous-Phase Metal-Catalyzed Reactions. Chem. Rev. 2009, 109, 643-710; (d) Butler, R. N.; Coyne, A. G. Water: Nature's Reaction Enforcer-Comparative Effects for Organic Synthesis "In-Water" and "On-Water". Chem. Rev. 2010, 110, 6302-6337; (e) Kitanosono, T.; Masuda, K.; Xu, P.; Kobayashi, S. Catalytic Organic Reactions in Water toward Sustainable Society. Chem. Rev. 2o18, 118, 679-746.

5. (a) Montalbetti, C. A. G. N.; Falque, V. Amide bond formation and peptide coupling. Tetrahedron 2005, 61, 10827-10852; (b) ElFaham, A.; Albericio, F. Peptide Coupling Reagents, More than a Letter Soup. Chem. Rev. 2011, 111, 6557-6602.

6. Schulz, J.; Císařová, I.; Štěpnička, P. Phosphinoferrocene Amidosulfonates: Synthesis, Palladium Complexes, and Catalytic Use in Pd-Catalyzed Cyanation of Aryl Bromides in an Aqueous Reaction Medium. Organometallics 2012, 31, 729-738.

7. For alternative approaches toward the synthesis of phosphino-amidosulfonates, see: (a) Nuzzo, R. G.; Feitler, D.; Whitesides, G. M. Water-soluble complexes of tertiary phosphines and rhodium(I) as homogeneous catalysts. J. Am. Chem. Soc. 1979, 101, 3683-3685; (b) Nuzzo, R.; Haynie, S. L.; Wilson, M. E.; Whitesides, G. M. Synthesis of functional chelating diphosphines containing the bis[2(diphenylphosphino)ethyl]amino moiety and the use of these materials in the preparation of water-soluble diphosphine complexes of transition metals. J. Org. Chem. 1981, 46, 2861-2867; (c) Fremy, G.; Castanet, Y.; Grzybek, R.; Monflier, E.; Morteux, A.; Trzeciak, A. M.; Ziolkowski, J. J. A new, highly selective, water-soluble rhodium catalyst for methyl acrylate hydroformylation. J. Organomet. Chem. 1995, 505, 11-16; (d) Lavenot, L.; Bortoletto, M. H.; Roucoux, A.; Larpent, C.; Patin, H. Synthesis of new hydrophilic phosphines by addition of diphenylphosphine on activated alkenes: characterization of their rhodium complexes. J. Organomet. Chem. 1996, 509, 9-14.

8. (a) Štěpnička, P. Phosphino-carboxamides: the inconspicuous gems. Chem. Soc. Rev. 2012, 41, 4273-4305; (b) Štěpnička, P. Coordination and catalytic chemistry of phosphinoferrocene carboxamides. Coord. Chem. Rev. 2017, 353, 223-246.

9. (a) Schulz, J.; Císařová, I.; Štěpnička, P. Synthesis of an amidosulfonate-tagged biphenyl phosphine and its application in the Suzuki-Miyaura reaction affording biphenyl-substituted amino acids in water. J. Organomet. Chem. 2015, 796, 65-72; (b) Schulz, J.; Horký, F.; Štěpnička, P. Different Performance of Two Isomeric Phosphinobiphenyl Amidosulfonates in Pd-Catalyzed Cyanation of Aryl Bromides. Catalysts 2016, 6, 182; (c) Schulz, J.; Horký, F.; Císařová, I.; Štěpnička, P. Synthesis, Structural Characterization and Catalytic Evaluation of Anionic Phosphinoferrocene Amidosulfonate Ligands. Catalysts 2017, 7, 167

10. (a) Ferrocenes: Homogeneous Catalysis, Organic Synthesis, Materials Science, Togni, A.; Hayashi, T.; Eds., VCH: Weinheim, 1995; (b) Ferrocenes: Ligands, Materials and Biomolecules, Štěpnička, P.; Ed.; Wiley: Chichester, 20o8; (c) Atkinson, R. C. J.; Gibson, V. C.; Long, N. J. The syntheses and catalytic applications of unsymmetrical ferrocene ligands. Chem. Soc. Rev. 2004, 33, 313-328; (d) Gómez Arrayás, R.; Adrio, J.; Carretero, J. C. Recent applications of chiral ferrocene ligands in asymmetric catalysis. Angew. Chem. Int. Ed. 20o6, $45,7674-7715$.

11. (a) Mom, S.; Beaupérin, M.; Roy, D.; Royer, S.; Amardeil, R.; Cattey, H.; Doucet, H.; Hierso, J.-C. Congested ferrocenyl polyphosphanes bearing electron-donating or electron-withdrawing phosphanyl groups: assessment of metallocene conformation from NMR spin couplings and use in palladium-catalyzed chloroarenes activation. Inorg. Chem. 2011, 50, 11592-116o3; (b) Thomas, D. A.; Ivanov, V. V.; Butler, I. R.; Horton, P. N.; Meunier, P.; Hierso, J.-C. Coordination Chemistry of Tetra- and Tridentate Ferrocenyl Polyphosphines: An Unprecedented [1,1'-Heteroannular and 2,3-Homoannular]-Phosphorus-Bonding Framework in a Metallocene Dinuclear Coordination Complex. Inorg. Chem. 20o8, 47, 1607-1615; (c) Beaupérin, M.; Smaliy, R.; Cattey, H.; Meunier, P.; Ou, J.; Toy, P. H.; Hierso, J.-C. Modular functionalized polyphosphines for supported materials: previously unobserved ${ }^{31} \mathrm{P}-\mathrm{NMR}$ ABCD spin systems and heterogeneous palladium-catalysed C-C and C-H arylation. Chem. Commun. 2014, 50, 9505-9508.

12. (a) Platon, M.; Roger, J.; Royer, S.; Hierso, J.-C. Palladium C-N bond formation catalyzed by air-stable robust polydentate ferrocenylphosphines: a comparative study for the efficient and selective coupling of aniline derivatives to dichloroarene. Catal. Sci. Tech. 2014, 4, 2072-208o; (b) Roger, J.; Mom, S.; Beaupérin, M.; Royer, S.; Meunier, P.; Ivanov, V. V.; Doucet, H.; Hierso, J.-C. Direct arylation of heterocycles: the performances of ferrocene-based polyphosphane ligands in palladium-catalyzed $\mathrm{C}-\mathrm{H}$ bond activation. ChemCatChem 2010, 2, 296-305; (c) Platon, M.; Wijaya, N.; Rampazzi, V.; Cui, L.; Rousselin, Y.; Saeys, M.; Hierso, J.-C. Thioetherification of Chloroheteroarenes: A Binuclear Catalyst Promotes Wide Scope and High Functional-Group Tolerance. Chem. Eur. J. 2014, 20, 1258412594 . 
13. (a) Evrard, D.; Lucas, D.; Mugnier, Y.; Meunier, P.; Hierso, J.-C. On the Mechanistic Behavior of Highly Efficient PalladiumTetraphosphine Catalytic Systems for Cross-Coupling Reactions: First Spectroscopic and Electrochemical Studies of Oxidative Addition on Pd(o)/Multidentate Ferrocenylpolyphosphine Complexes. Organometallics 20o8, 27, 2643-2653; (b) Zinovyeva, V. A.; Mom, S.; Fournier, S.; Devillers, C. H.; Cattey, H.; Doucet, H.; Hierso, J.-C.; Lucas, D. Kinetic and Electrochemical Studies of the Oxidative Addition of Demanding Organic Halides to Pd(o): the Efficiency of Polyphosphane Ligands in Low Palladium Loading Cross-Couplings Decrypted. Inorg. Chem. 2013, 52, 11923-11933.

14. (a) Chanda, A.; Fokin, V. V. Organic Synthesis "On Water". Chem. Rev. 2oog, 109, 725-748; (b) Kitanosono, T.; Kobayashi, S. Reactions in Water Involving the "On-Water" Mechanism. Chem. Eur. J. 2020, 26, 9408-9429.

15. Lerayer, E.; Renaut, P.; Roger, J.; Pirio, N.; Cattey, H.; Devillers, C.-H.; Lucas, D.; Hierso, J.-C. A general diastereoselective synthesis of highly functionalized ferrocenyl ambiphiles enabled on a large scale by electrochemical purification. Chem. Commun. 2017, 53, 6o176020 .

16. Radal, L.; Vosáhlo, P.; Roger, J.; Cattey, H.; Amardeil, H.; Císařová, I.; Štěpnička, P.; Pirio, P.; Hierso, J.-C. Highly functionalized Brønsted acidic/Lewis basic hybrid ferrocene ligands: synthesis and coordination chemistry. Eur. J. Inorg. Chem. 2019, 865-874.

17. Imamoto, T.; Oshiki, T.; Onozawa, T.; Kusumoto, T.; Sato, K. Synthesis and Reaction of phosphine-Boranes. Synthesis of New Bidentate Ligands with Homochiral Phosphine Centers via Optically Pure Phosphine-Boranes. J. Am. Chem. Soc. 1990, 112, 5244-5252 and ref. 9 c.

18. Tomasi, J.; Mennucci, B.; Cammi, R. Quantum Mechanical Continuum Solvation Models. Chem. Rev. 2005, 150, $2999-3093$.

19. (a) Aullón, G.; Alvarez, S. Axial Bonding Capabilities of Square Planar d ${ }^{8}-\mathrm{ML}_{4}$ Complexes. Theoretical Study and Structural Correlations. Inorg. Chem. 1996, 35, 3137-3144.

20. (a) Platon, M.; Amardeil, R.; Djakovitch, L.; Hierso, J.-C. Progress in palladium-based catalytic systems for the sustainable synthesis of annulated heterocycles: a focus on indole backbones. Chem. Soc. Rev. 2o12, 41, 3929-3968; (b) Humphrey, G. R.; Kuethe, J. T. Practical Methodologies for the Synthesis of Indoles. Chem. Rev. 20o6, 106, 2875-2911; (c) Krüger, K; Tillack, A.; Beller, M. Catalytic Synthesis of Indoles from Alkynes. Adv. Synth. Catal. 2oo8, 350, 2153-2167; d) R. Vicente. Recent advances in indole syntheses: New routes for a classic target. Org. Biomol. Chem. 2011, 9, 6469-6480.

21. Cacchi, S.; Fabrizi, G. Synthesis and Functionalization of Indoles Through Palladium-catalyzed Reactions. Chem. Rev. 2005, 105, 2873-2920.

22. (a) Yamaguchi, A. D.; Itami, K. C-H Bond Functionalization: Emerging Synthetic Tools for Natural Products and Pharmaceuticals. Angew. Chem. Int. Ed. 2012, 51, 8960-9009; (b) Moncea, O.; Poinsot, D.; Fokin, A. A.; Schreiner, P. R.; Hierso, J.-C. Palladium-Catalyzed $\mathrm{C}_{2}-\mathrm{H}$ Arylation of Unprotected (N-H)-Indoles "On Water" Using Primary Diamantyl Phosphine Oxides as a Class of Primary Phosphine Oxide Ligands. ChemCatChem 2018, 10, 2915-2922. For examples exploiting substituted indoles and different arylating agents, see: (c) Y. Zhu, M. Bauer, L. Ackermann. Late-Stage Peptide Diversification by Bioorthogonal Catalytic C-H Arylation at $23^{\circ} \mathrm{C}$ in $\mathrm{H}_{2} \mathrm{O}$. Chem. Eur. J. 2015, 21, 9980-9983; (d) A. J. Reay, L. A. Hammarback, J. T. W. Bray, T. Sheridan, D. Turnbull, A. C. Whitwood, I. J. S. Fairlamb. Mild and Regioselective $\mathrm{Pd}(\mathrm{OAc})_{2}$-Catalyzed $\mathrm{C}-\mathrm{H}$ Arylation of Tryptophans by $\left[\mathrm{ArN}_{2}\right] \mathrm{X}$, Promoted by Tosic Acid. ACS Catal. 2017, 7, 51745179; (e) N. Vasudevan, E. Wimmer, E. Barré, D. Cortés-Borda, M. Rodriguez-Zubiri, F.-X. Felpin. Direct C-H Arylation of Indole-3Acetic Acid Derivatives Enabled by an Autonomous Self-Optimizing Flow Reactor. Adv. Synth. Catal. 2021, 363, $791-799$.

23. Sheldrick, G. M. SHELXT - Integrated space-group and crystal-structure determination. Acta Crystallogr., Sect. A: Found. Adv. 2015, 71, 3-8.

24. Sheldrick, G. M. Crystal structure refinement with SHELXL. Acta Crystallogr., Sect. C: Struct. Chem. 2o15, 71, 3-8.

25. Spek, A. L. PLATON SQUEEZE: a tool for the calculation of the disordered solvent contribution to the calculated structure factors. Acta Crystallogr., Sect. C: Struct. Chem. 2015, 71, 9-18.

26. (a) Spek, A. L. Single-crystal structure validation with the program PLATON. J. Appl. Crystallogr. 2003, 36, 7-13; (b) Spek, A. L. Structure validation in chemical crystallography. Acta Crystallogr. D, Biol. Crystallogr. 2009, 65, 148-155.

27. Gaussian 16, Revision C.o1, M. J. Frisch, G. W. Trucks, H. B. Schlegel, G. E. Scuseria, M. A. Robb, J. R. Cheeseman, G. Scalmani, V. Barone, G. A. Petersson, H. Nakatsuji, X. Li, M. Caricato, A. V. Marenich, J. Bloino, B. G. Janesko, R. Gomperts, B. Mennucci, H. P. Hratchian, J. V. Ortiz, A. F. Izmaylov, J. L. Sonnenberg, D. Williams-Young, F. Ding, F. Lipparini, F. Egidi, J. Goings, B. Peng, A. Petrone, T. Henderson, D. Ranasinghe, V. G. Zakrzewski, J. Gao, N. Rega, G. Zheng, W. Liang, M. Hada, M. Ehara, K. Toyota, R. Fukuda, J. Hasegawa, M. Ishida, T. Nakajima, Y. Honda, O. Kitao, H. Nakai, T. Vreven, K. Throssell, J. A. Montgomery, Jr., J. E. Peralta, F. Ogliaro, M. J. Bearpark, J. J. Heyd, E. N. Brothers, K. N. Kudin, V. N. Staroverov, T. A. Keith, R. Kobayashi, J. Normand, K. Raghavachari, A. P. Rendell, J. C. Burant, S. S. Iyengar, J. Tomasi, M. Cossi, J. M. Millam, M. Klene, C. Adamo, R. Cammi, J. W. Ochterski, R. L. Martin, K. Morokuma, O. Farkas, J. B. Foresman, and D. J. Fox, Gaussian, Inc., Wallingford CT, 2016.

28. Adamo, C.; Barone, V. Toward reliable density functional methods without adjustable parameters: The PBEo model. J. Chem. Phys. 1999, 110, 6158-6170.

29. (a) Dolg, M.; Wedig, U.; Stoll, H.; Preuss, H. Energy-adjusted $a b$ initio pseudopotentials for the first row transition elements. J. Chem. Phys. 1987, 86, 866-872; (b) Andrae, D.; Häussermann, U.; Dolg, M.; Stoll, H.; Preuss, H. Energy-adjusted ab initio pseudopotentials for the second and third row transition elements. Theor. Chim. Acta 1990, 77, 123-141.

3o. Papajak, E.; Zheng, J.; Xu, X.; Leverentz, H. R.; Truhlar, D. G. Perspective on Basis Sets Beautiful: Seasonal Plantings of Diffuse Basis Functions. J. Chem. Theory Comput. 2011, 7, 3027-3034. 